Article

\title{
Bioremediation by Cupriavidus metallidurans Strain MSR33 of Mercury-Polluted Agricultural Soil in a Rotary Drum Bioreactor and Its Effects on Nitrogen Cycle Microorganisms
}

\author{
Guillermo Bravo ${ }^{1, *}$, Paulina Vega-Celedón ${ }^{1}$, Juan Carlos Gentina ${ }^{2}\left[\right.$ and Michael Seeger ${ }^{1, *}$ \\ 1 Molecular Microbiology and Environmental Biotechnology Laboratory, Department of Chemistry \& Center \\ of Biotechnology Daniel Alkalay Lowitt, Universidad Técnica Federico Santa María, Avenida España 1680, \\ Valparaíso 2390123, Chile; pvegaceledon@gmail.com \\ 2 School of Biochemical Engineering, Pontificia Universidad Católica de Valparaíso, Avenida Brasil 2085, \\ Valparaíso 2362803, Chile; carlos.gentina@pucv.cl \\ * Correspondence: bravoc.guillermo@gmail.com (G.B.); michael.seeger@gmail.com (M.S.); \\ Tel.: +56-3226-54236 (M.S.)
}

Received: 16 November 2020; Accepted: 7 December 2020; Published: 9 December 2020

check for updates

\begin{abstract}
Nitrogen cycle microorganisms are essential in agricultural soils and may be affected by mercury pollution. The aims of this study are to evaluate the bioremediation of mercury-polluted agricultural soil using Cupriavidus metallidurans MSR33 in a rotary drum bioreactor (RDB) and to characterize the effects of mercury pollution and bioremediation on nitrogen cycle microorganisms. An agricultural soil was contaminated with mercury (II) (20-30 ppm) and subjected to bioremediation using strain MSR33 in a custom-made RDB. The effects of mercury and bioremediation on nitrogen cycle microorganisms were studied by qPCR. Bioremediation in the RDB removed $82 \%$ mercury. MSR33 cell concentrations, thioglycolate, and mercury concentrations influence mercury removal. Mercury pollution strongly decreased nitrogen-fixing and nitrifying bacterial communities in agricultural soils. Notably, after soil bioremediation process nitrogen-fixing and nitrifying bacteria significantly increased. Diverse mercury-tolerant strains were isolated from the bioremediated soil. The isolates Glutamicibacter sp. SB1a, Brevundimonas sp. SB3b, and Ochrobactrum sp. SB4b possessed the $m e r G$ gene associated with the plasmid pTP6, suggesting the horizontal transfer of this plasmid to native gram-positive and gram-negative bacteria. Bioremediation by strain MSR33 in an RDB is an attractive and innovative technology for the clean-up of mercury-polluted agricultural soils and the recovery of nitrogen cycle microbial communities.
\end{abstract}

Keywords: Cupriavidus metallidurans; mercury; nitrogen cycle; rotary drum bioreactor; soil bioremediation

\section{Introduction}

Lands for agriculture are degraded due to pollution and other anthropogenic activities [1]. Anthropogenic activities have significantly perturbed the soil nitrogen cycle [2-5]. Nitrogen is an essential nutrient for all forms of life and a key element in the agroecological system $[6,7]$. Nitrogen cycle balance in soils is influenced principally by microbial nitrogen fixation, nitrification, and denitrification [8]. In agricultural soils, nitrogen-fixing bacteria is an indicator of soil quality [7,9]. Nitrogen-fixing microorganisms contribute to plants productivity and are essential in agricultural systems $[6,10,11]$. Nitrification is performed by bacteria and archaea, which oxidize ammonia to nitrite and nitrate $[2,8]$. These conversions could affect agricultural soil, due to losses generated by the high 
solubility of nitrate that may cause groundwater eutrophication. Denitrification is a process in which nitrate is reduced successively to $\mathrm{NO}, \mathrm{N}_{2} \mathrm{O}$, and $\mathrm{N}_{2}$ gases, and may affect agricultural soil due to nitrogen release into the atmosphere $[5,8,12]$.

The presence of heavy metals in the environment harms ecosystems, affecting agricultural soil quality and human health [13]. Mercury pollution of agricultural soil is caused mainly by mercurial compounds present in pesticides, seed-coat dressing, mercury-polluted manures, disinfectants, pharmaceuticals, and the mobilization of metal-containing sludge [13-16]. Mercury is a toxic heavy metal that causes deleterious effects on organisms due to its high affinity to sulfhydryl and thioester groups on proteins [17,18]. Mercury causes growth arrest, oxidative stress, disruption of the integrity of cell membranes, interference with the electron transport system, enzymatic inhibition, and replacement of metallic centers of metalloproteins [19-22]. Heavy metal pollution causes major changes in soil microbial composition and their activities $[3,13,23]$. In plants, mercury replaces the central magnesium atom of chlorophyll, interrupting photosynthesis, and decreasing photosynthetic pigments, causing damage to agricultural systems [14,24].

Bioremediation is an eco-friendly and low-cost treatment based on the capability of bacteria, fungi, archaea, and plants to remove or transform compounds or elements into less toxic forms [22,25-28]. Mercury bioremediation by mercury-resistant bacteria is based on the reduction of $\mathrm{Hg}$ (II) to gaseous $\mathrm{Hg}(0)$ by proteins encoded by the mer genes [16,19,29-33]. Cupriavidus metallidurans is a facultative anaerobic bacterium capable of removing heavy metals $(\mathrm{Hg}, \mathrm{Cd}, \mathrm{Cu})$ and degrading toxic organic pollutants such as toluene under aerobic and anaerobic conditions [19,22,34-37]. C. metallidurans strain MSR33 is a transconjugant derivative of $\mathrm{C}$. metallidurans $\mathrm{CH} 34$, which contains the environmental plasmid pTP6 [19]. Strain MSR33 possesses an increased mercury resistance (2.4-fold), reducing $\mathrm{Hg}$ (II) and organomercurial compounds into $\mathrm{Hg}(0)$ under aerobic and anaerobic conditions [19,22]. A method for the bioremediation of environments polluted with mercury, copper, and cadmium using C. metallidurans strain MSR33 has been patented [38]. Several processes for mercury bioremediation from aqueous solutions have been described $[19,22,29,39,40]$. However, the bioremediation of mercury-polluted soil has been scarcely studied. Bioaugmentation using zeolite immobilized Pseudomonas veronii of mine tailing soil polluted with $\mathrm{Hg}$ (II) (7 ppm) increases 4-fold the background mercury volatilization [31]. Bioremediation using the fungus Lecythophora sp. DC-F1 and biochar of mercury-polluted soil (30 ppm) reported 13.3-26.1\% mercury removal after 56 days [41]. Phytoremediation using Triticum aestivum showed 70\% mercury removal in mercury-polluted soil ( 30 ppm) after 3 years [42]. The hybrid plant Miscanthus $\times$ giganteus showed a mercury removal rate of $4 \mu \mathrm{g}$ year $^{-1}$ in $\mathrm{Hg}$-polluted soil (20 ppm) [43].

Rotary drums are used in industrial processes of drying, incineration, humidification, mixing of solid particles, and biological applications, such as microbial biomass production and soil bioremediation [44-49]. Rotary drum bioreactor (RDB) is an attractive alternative for ex situ soil bioremediation due to its absence of internal moving parts for mixing, simple construction, simple operation, and reduced aeration costs $[47,48]$. The soil bioremediation of fluorene, anthracene, phenanthrene, pyrene, toluene, diethyl ether, hexane, synthetic dyes, and petroleum hydrocarbon in RDB were described [44-46,50,51]. Bioleaching processes of metals on RDB were described for gold, copper, zinc, and nickel ores [52].

The aims of this study are to evaluate the bioremediation of mercury-polluted agricultural soil using Cupriavidus metallidurans MSR33 in a rotary drum bioreactor (RDB) and to characterize the effects of mercury pollution and bioremediation on nitrogen cycle microorganisms. The mercury bioremediation in a custom-made RDB was performed. The effects of MSR33 cell concentrations (6 and $3 \mathrm{~g}$ cells $\mathrm{kg}^{-1}$ dry soil), thioglycolate $(5 \mathrm{mM})$, and $\mathrm{Hg}$ (II) concentrations (20 and $30 \mathrm{ppm}$ ) on mercury soil removal were studied. Mercury showed a negative effect on nitrogen-fixing and nitrifying bacterial communities in agricultural soils. In contrast, after bioremediation by strain MSR33, nitrogen-fixing and nitrifying bacterial communities significantly increased. Six mercury-tolerant strains were isolated from bioremediated soils. The isolates were identified as Glutamicibacter sp. SB1a, 
Bacillus sp. SB1b, Planomicrobium sp. SB2b, Bergeyella sp. SB2a, Brevundimonas sp. SB3b, and Ochrobactrum sp. SB4b. Glutamicibacter sp. SB1a, Brevundimonas sp. SB3b, and Ochrobactrum sp. SB4b possess the merG gene that is associated with the plasmid pTP6, suggesting the horizontal transfer of this plasmid from C. metallidurans strain MSR33 to native gram-positive and gram-negative soil bacteria.

\section{Materials and Methods}

\subsection{Chemicals}

Succinate, $\mathrm{HgCl}_{2}$, sodium thioglycolate, $\mathrm{H}_{2} \mathrm{SO}_{4}, \mathrm{NH}_{4} \mathrm{Cl}, \mathrm{NaH}_{2} \mathrm{PO}_{4} \times 2 \mathrm{H}_{2} \mathrm{O}, \mathrm{KCl}, \mathrm{HCl}, \mathrm{NaOH}$, agarose, and KAPA SYBR FAST qPCR Master Mix were purchased from Merck (Darmstadt, Germany). Primers (Table 1) were purchased from IDT (Coralville, IA, USA). FastDNA Spin Kit for soil and GeneClean II Spin Kit were purchased from MP Biomedicals (Solon, OH, USA). GoTaq Green Master Mix was purchased from Promega (Madison, WI, USA). GelRed Nucleic Acid Gel Stain was purchased from Biotium (Fremont, CA, USA). Cycloheximide was purchased from USBiological (Salem, MA, USA).

Table 1. Primers used in this study.

\begin{tabular}{|c|c|c|c|c|}
\hline Primers & Sequence $\left(5^{\prime}-3^{\prime}\right)$ & Gene Target & Size $(\mathrm{pb})$ & Reference \\
\hline $27 \mathrm{~F}$ & AGAGTTTGATCMTGGCTCAG & \multirow{2}{*}{ 16S rRNA } & \multirow{2}{*}{1465} & \multirow{2}{*}{ [53] } \\
\hline $1492 R$ & TACGGYTACCTTGTTACGACTT & & & \\
\hline nifH-F-Rösch & AAAGGYGGWATCGGYAARTCCACCA & \multirow{2}{*}{ nifH } & \multirow{2}{*}{458} & \multirow{2}{*}{ [54] } \\
\hline nifH-R-Rösch & TTGTTSGCSGCRTACATSGCCATCAT & & & \\
\hline $\begin{array}{l}\text { amoA-1F } \\
\text { amoA-2R }\end{array}$ & $\begin{array}{c}\text { GGGGTTTCTACTGGTGGT } \\
\text { CCСCTCKGSAAAGCCTTCTTC }\end{array}$ & $\mathrm{AOB}$ amoA & 491 & {$[55]$} \\
\hline zniA_F & GGAAAGGCCTTCCTGGACAT & \multirow[b]{2}{*}{$z n i A$} & \multirow{2}{*}{167} & \multirow{4}{*}{$\begin{array}{l}\text { L. Rojas, personal } \\
\text { communication } \\
\text { L. Rojas, personal } \\
\text { communication }\end{array}$} \\
\hline zniA_R & TCAACGCGGAGTTCTTCGTA & & & \\
\hline merG_F & AGTACCGCAACGTTAGGCAT & \multirow{2}{*}{ merG } & \multirow{2}{*}{171} & \\
\hline merG_R & ACCGCATTTGTACGCAAGAC & & & \\
\hline
\end{tabular}

\subsection{Strains}

Cupriavidus metallidurans MSR33 (positive control for the zniA and merG genes) and Paraburkholderia xenovorans LB400 (positive control for the nifH gene) were obtained from the culture collection of Molecular Microbiology and Environmental Biotechnology Laboratory, Universidad Técnica Federico Santa María (Valparaíso, Chile). Escherichia coli clone AOB amoA (positive control for the AOB amoA gene) was kindly provided by Julieta Orlando, Faculty of Sciences, Universidad de Chile (Santiago, Chile).

\subsection{Agricultural Soil Samples}

Non-polluted agricultural sandy loam soil samples were collected at Casablanca valley, Central Chile in March 2016, as described by Altimira et al. [3]. The non-polluted site was located in La Vinilla (longitude $71^{\circ} 24^{\prime} 36^{\prime \prime} \mathrm{W}$ and latitude $32^{\circ} 19^{\prime} 30.254^{\prime \prime} \mathrm{S}$ ). Previous soil analysis determined $2.3 \%$ organic matter content, low heavy metal content, and neutral $\mathrm{pH}$ [3]. Soil samples were air-dried, 2 mm sieved, and homogenized. The soil samples were stored in polyethylene bags and preserved in a dark room at $4{ }^{\circ} \mathrm{C}$ until analyses.

\subsection{Preparation of Mercury-Polluted Agricultural Soil}

Agricultural soil was spiked with $\mathrm{HgCl}_{2}$ solutions to obtain mercury-polluted soil (20 and $30 \mathrm{ppm}$ ). The soil suspension was homogenized with a ceramic mortar, dried for 7 days at $30{ }^{\circ} \mathrm{C}$, and crushed to recover the original granulometry $(2 \mathrm{~mm})$. Subsequently, mercury content in soil was determined by atomic absorption spectrometry [22]. 


\subsection{Batch Culture Growth}

Batch culture growth of strain MSR33 was performed in a stirred-tank bioreactor Ez-control (Applikon Biotechnology, Delft, The Netherlands) of $3 \mathrm{~L}$ total volume, equipped with a Rushton type turbine and $\mathrm{pH}$ and temperature controllers. MSR33 cells were grown in GBC medium ( $\mathrm{pH} 7)$ with succinate $\left(8 \mathrm{~g} \mathrm{~L}^{-1}\right)$ in $1 \mathrm{~L}$ fermentation volume with agitation $(500 \mathrm{rpm})$, aeration (airflow of $2 \mathrm{vvm}$ ) and at $30^{\circ} \mathrm{C}$ [22]. Previously, MSR33 cells grown in Luria-Bertani broth medium (until late exponential phase) were harvested and inoculated at $10 \% v / v$ in the fermentation volume. The bacterial cultures were collected at early stationary phase for the inoculation in soil during bioremediation assays.

\subsection{Bioremediation of Mercury-Polluted Agricultural Soils in a Rotary Drum Bioreactor (RDB)}

An acrylic RDB of $20 \mathrm{~L}$ and 8 internal lifters ( $5 \mathrm{~cm}$ width), equipped with a humidified air injection system and mercury gas oxidizing trap $\left(\mathrm{HNO}_{3} 1 \mathrm{M}\right)$, was designed, and built. The RDB was used for bioremediation treatments using C. metallidurans MSR33 of mercury-polluted soils (Figure 1). Agricultural soil bioremediation treatments were performed in a thermo-regulated chamber $\left(30 \pm 3^{\circ} \mathrm{C}\right)$, a constant drum rotation speed of $10 \mathrm{rpm}$, and a humidified air injection of $1 \mathrm{vvm}$. All treatments were evaluated by mixing a cell-culture suspension and soil in a 2:1 ratio. $500 \mathrm{~g}$ of mercury-polluted soils and $1 \mathrm{~L}$ cell culture of strain MSR33 were mixed in the RDB during soil bioremediation assay. Negative controls were performed using sterile distilled water and soil in a 2:1 ratio. For each treatment, samples in duplicate were analysed.

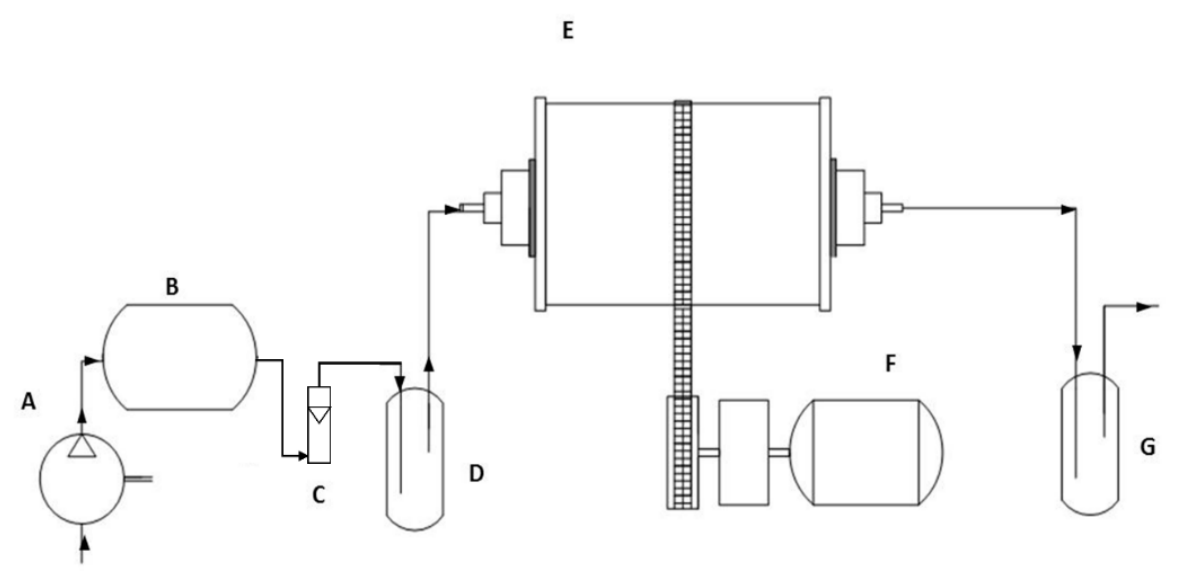

Figure 1. Flow chart of the designed and custom-made rotary drum bioreactor (RDB) for the bioremediation of mercury-polluted agricultural soils. (A) Air compressor; (B) Air accumulator balloon; (C) Air rotameter; (D) Air humidifier; (E) RDB; (F) Rotation mechanism; (G) Mercury gas oxidizing trap containing $\mathrm{HNO}_{3}(1 \mathrm{M})$. Arrows indicate gas flow during operation. $\mathrm{Hg}$ (II) in polluted soil is reduced to $\mathrm{Hg}(0)$ gaseous by $C$. metallidurans MSR33 in the RDB (E). Gas is displaced from the RDB by air injection (A-D). Gaseous $\mathrm{Hg}(0)$ is captured by gas stripping in an oxidizing trap, where $\mathrm{Hg}(0)$ is oxidized to $\mathrm{Hg}$ (II) (G).

The effect of cell concentration on mercury bioremediation was evaluated during $72 \mathrm{~h}$ using 6 and $3 \mathrm{~g}$ cells $\mathrm{kg}^{-1}$ dry soil, and mercury-polluted soils (20 ppm).

The effect of thioglycolate application on mercury bioremediation was evaluated using $6 \mathrm{~g}$ cells $\mathrm{kg}^{-1}$ dry soil, and mercury-polluted soils ( $\left.20 \mathrm{ppm}\right)$. Thioglycolate $(5 \mathrm{mM})$ was added at the beginning of the assay. Soil bioremediation assays were evaluated during $96 \mathrm{~h}$.

The re-inoculation assay was conducted using $6 \mathrm{~g}$ cells kg-1 $\mathrm{dry}$ soil and mercury-polluted soils (20 ppm). At $48 \mathrm{~h}$ after the bioremediation started, MSR33 cells ( $6 \mathrm{~g}$ cells kg${ }^{-1} \mathrm{dry}$ soil) were inoculated in the RDB. MSR33 cells from $1 \mathrm{~L}$ batch culture were collected in a Hettich model Rotina 380R centrifuge (Kirchlengern, Germany) at 3500 $\mathrm{g}$ for $10 \mathrm{~min}$. Soil bioremediation assays were run during $96 \mathrm{~h}$. 
The effect of mercury content in soil on bioremediation was evaluated during $72 \mathrm{~h}$ using $6 \mathrm{~g}$ cells $\mathrm{kg}^{-1}$ dry soil and mercury-polluted soils (20 and $30 \mathrm{ppm}$ ).

\subsection{Soil Mercury Determination}

For the determination of $\mathrm{Hg}$ in soil samples (1.5 g), the AOAC 977.15 methodology was used with modifications [56]. The mercury quantification was carried out by cold vapor atomic absorption spectrometry using an atomic absorption spectrometer Agilent model 240AA series AA1110M032 (Santa Clara, CA, USA), with a hydride generation module (VGA 77) [22].

\subsection{Bacterial Count and Isolation of Mercury-Tolerant Strains}

Heterotrophic bacteria and mercury-tolerant bacteria in soil were quantified. Each moist soil sample ( $1 \mathrm{~g}$ ) was diluted in $9 \mathrm{~mL}$ of PBS (phosphate-buffered saline). The dilution was mixed vigorously and subjected to orbital agitation of $200 \mathrm{rpm}$ for $30 \mathrm{~min}$. Serial dilutions of the suspensions were grown in TSA in the absence or presence of mercury (II) (10 ppm) [3]. To prevent fungal growth, cycloheximide $\left(100 \mu \mathrm{g} \mathrm{L}^{-1}\right)$ was added to the culture medium [57]. The plates were incubated at $30^{\circ} \mathrm{C}$. Heterotrophic and mercury-tolerant cultivable bacteria were counted after $72 \mathrm{~h}$. To determine the CFU $\mathrm{g}^{-1}$ dry soil, the soil moisture was determined on a Moisture Analyzer Sartorius MA 35 (Göttingen, Germany). MSR33 colonies were determined based on their capability to grow in the presence of $\mathrm{Hg}$ (II) $(10 \mathrm{ppm})$. Novel mercury-tolerant bacterial strains were isolated and identified.

\subsection{Genomic DNA Extraction from Bacterial Isolates and PCR Amplification of $16 S$ rRNA and merG Genes}

Genomic DNA was prepared from single colonies suspended in $100 \mu \mathrm{L}$ of sterile milli-Q water, heated at $95{ }^{\circ} \mathrm{C}$ for $5 \mathrm{~min}$, and centrifuged briefly [3]. The supernatant $(2 \mu \mathrm{L})$ was used for PCR amplification. PCR reactions were conducted in a volume of $25 \mu \mathrm{L}$ containing specific primers $(0.6 \mu \mathrm{M}$ each), GoTaq Master Mix reagent $(12.5 \mu \mathrm{L})$, and $1 \mu \mathrm{L}$ genomic DNA. The forward $27 \mathrm{~F}$ and reverse 1492R primers were used for the $16 \mathrm{~S}$ rRNA gene amplification (Table 1). The forward merG_F and reverse merG_R primers were used for the $m e r G$ gene amplification (Table 1).

DNA amplification of the 16S rRNA gene was carried out using the following conditions: 1 cycle of $95^{\circ} \mathrm{C}$ for $5 \mathrm{~min}, 30$ cycles of $95^{\circ} \mathrm{C}$ for $1 \mathrm{~min}, 55^{\circ} \mathrm{C}$ for $1 \mathrm{~min}, 72^{\circ} \mathrm{C}$ for $1.5 \mathrm{~min}$, and a final extension of $72{ }^{\circ} \mathrm{C}$ for $10 \mathrm{~min}$. Amplification of the $\mathrm{mer} G$ gene was carried out using the following conditions: 1 cycle of $95^{\circ} \mathrm{C}$ for $3 \mathrm{~min}, 35$ cycles of $95^{\circ} \mathrm{C}$ for $30 \mathrm{~s}, 55^{\circ} \mathrm{C}$ for $30 \mathrm{~s}, 72{ }^{\circ} \mathrm{C}$ for $30 \mathrm{~s}$, and a final extension of $72{ }^{\circ} \mathrm{C}$ for $5 \mathrm{~min}$. C. metallidurans MSR33 genomic DNA was used as a positive control for the mer $\mathrm{G}$ gene. PCR products were visualized by agarose gel electrophoresis $(2 \% w / v)$, followed by staining with GelRed Nucleic Acid Gel Stain (1:10,000 v/v).

\subsection{0. $16 S$ rRNA Gene Sequence Analyses}

The 16S rRNA gene amplification products were quantified using the Qubit fluorometer (Invitrogen, Carlsbad, CA, USA). The partial 16S rRNA gene PCR products were sequenced using the primer 800R in Macrogen Inc. (Seoul, Korea). The sequences were compared with the Genbank NCBI databases to determine the genera of the bacterial strains. A phylogenetic analysis was performed to study the evolutionary relationships of the sequences based on the alignments calculated by CLUSTAL $\mathrm{W}$ using the default options. The evolutionary history was inferred using the neighbor-joining method. Evolutionary analyses were conducted in MEGA 5.2.2 software [58]. The 16S rRNA gene sequences were deposited in GenBank under the following accession numbers: Glutamicibacter sp. SB1a (MT953323), Bacillus sp. SB1b (MT953319), Planomicrobium sp. SB2b (MT953320), Bergeyella sp. SB2a (MT953324), Brevundimonas sp. SB3b (MT953321), and Ochrobactrum sp. SB4b (MT953322). 


\subsection{Metagenomic DNA Extraction from Agricultural Soil}

Metagenomic DNA from agricultural soils was extracted. Total soil DNA was extracted from $0.5 \mathrm{~g}$ of dry soil using the FastDNA Spin Kit for soil with mechanical lysis by two pulses at $5.5 \mathrm{~m} \mathrm{~s}^{-1}$ per $30 \mathrm{~s}$ in the FastPrep-24 Bead-Beater Instrument (MP Biomedicals, Solon, OH, USA). After DNA extraction from the soil, DNA was directly purified with the GeneClean II Spin Kit following the manufacturer's instructions. Purified DNA samples were quantified using the Qubit fluorometer according to the manufacturer's instructions.

\subsection{Quantification of Nitrogen Cycle-Associated Bacteria and Strain MSR33 in Agricultural Soils}

The standard-curve method of absolute quantification was used for the analysis of nitrogen cycle-associated nifH (nitrogen fixation) and AOB amoA (nitrification) genes, strain MSR33 zniA gene (chromid) and plasmid pTP6 merG gene. Agricultural soil metagenomic DNA samples were subjected to quantitative PCR (qPCR) of these genes.

Genomic DNA of P. xenovorans LB400 was used for the nifH gene detection, E. coli clone AOB amoA for the AOB amoA gene detection, and C. metallidurans MSR33 for the zniA and merG genes detection. The qPCR was done on a Stratagene Mx3000pTM (Agilent Technologies, Santa Clara, CA, USA), using the KAPA SYBR FAST qPCR Master Mix reagent and $0.2 \mu \mathrm{M}$ from each primer (Table 1) following the manufacturer's instructions. The amplification of a single PCR product for each pair of primers was confirmed by fusion curves.

The standard curves for each amplicon were performed in triplicate by serial dilutions (1:10) of genomic DNA from the positive controls of nifH, AOB amoA, zniA, and merG genes. The efficiency of the qPCR reaction for each gene was calculated from the slopes of the exponential portion of the calibration curves. The gene copy number per gram of soil was determined according to the methodology described by Brankatschk et al. [59]. Absolute qPCR of nifH, AOB amoA, zniA and merG genes were carried out using the following conditions: 1 cycle at $95^{\circ} \mathrm{C}$ for $3 \mathrm{~min}, 40$ cycles at $95^{\circ} \mathrm{C}$ for $30 \mathrm{~s}, 55^{\circ} \mathrm{C}$ for $30 \mathrm{~s}, 72{ }^{\circ} \mathrm{C}$ for $30 \mathrm{~s}$, and a final extension at $72{ }^{\circ} \mathrm{C}$ for $5 \mathrm{~min}$.

\subsection{Statistical Analysis}

The data were analysed by one-way ANOVA. After carrying out one-way ANOVA, Fisher's LSD test was used to determine significant differences $(p<0.05)$ among the treatments.

\section{Results}

\subsection{Evaluation of Operational Parameters on Bioremediation by Strain MSR33 of Mercury-Polluted} Agricultural Soil in an $R D B$

A bioremediation process of mercury-polluted soils with C. metallidurans strain MSR33 in a custom-made RDB was established. Mercury (II) removal kinetics variables: cellular concentration, thioglycolate, re-inoculation, and mercury concentration were evaluated (Figures 2 and 3).

Mercury bioremediation with MSR33 cell concentrations of 6 and $3 \mathrm{~g}$ cells $\mathrm{kg}^{-1}$ dry soil were evaluated. Bioremediation performed with a high concentration of MSR33 cells $(6 \mathrm{~g}$ cells kg-1 dry soil) showed a higher mercury removal after $48 \mathrm{~h}$ (70\% mercury removal) than with $3 \mathrm{~g}$ cells $\mathrm{kg}^{-1}$ dry soil. However, after $72 \mathrm{~h}$, both treatments reached a similar mercury residual concentration in soil $(6.16 \pm 0.06 \mathrm{ppm}$ and $6.43 \pm 0.08 \mathrm{ppm}$, respectively) (Figure 2).

The effect of thioglycolate on $\mathrm{Hg}$ (II) $(20 \mathrm{ppm})$ removal was determined. Thioglycolate $(5 \mathrm{mM})$ increased the mercury removal $(82 \%)$, reaching a lower concentration of residual mercury $(2.53 \pm 0.014 \mathrm{ppm})$ in soil after $72 \mathrm{~h}$, compared to mercury removal by treatment without thioglycolate (70\%). The effect of re-inoculation on the mercury bioremediation process was also studied. A second inoculation with $6 \mathrm{~g}$ cells $\mathrm{kg}^{-1}$ dry soil at $48 \mathrm{~h}$ showed no changes in mercury removal from polluted soils compared with bioremediation treatments without re-inoculation. Re-inoculation treatment reached a residual mercury concentration of $6.27 \pm 0.06 \mathrm{ppm}$ after $72 \mathrm{~h}$. The effect of a higher concentration of 
mercury (II) (30 ppm) on soil bioremediation by strain MSR33 in RDB was evaluated with $6 \mathrm{~g}$ cells $\mathrm{kg}^{-1}$ dry soil (Figure 3). Strain MSR33 removed $80 \%$ of mercury after $72 \mathrm{~h}$, achieving a residual concentration of $5.81 \pm 0.34 \mathrm{ppm}$ mercury in soil. Similar removal kinetics behavior was observed in soils polluted with mercury 20 ppm (Figure 2).

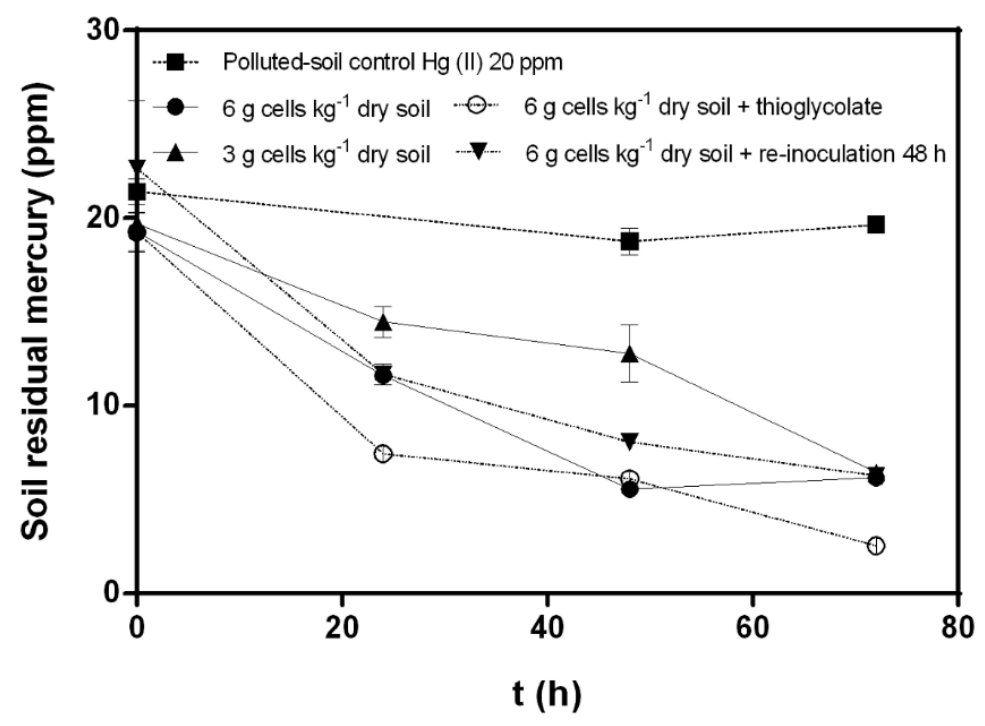

Figure 2. Effects of cellular concentration, thioglycolate, and cellular re-inoculation on mercury (II) (20 ppm) bioremediation by C. metallidurans MSR33 on mercury-polluted agricultural soil in a rotary

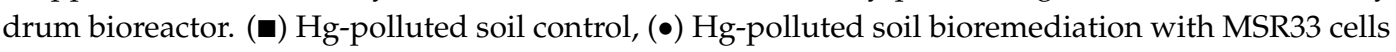
concentration of $6 \mathrm{~g}$ cells $\mathrm{kg}^{-1}$ dry soil, ( $\left.\mathbf{\Delta}\right) \mathrm{Hg}$-polluted soil bioremediation with MSR33 cells concentration of $3 \mathrm{~g}$ cells $\mathrm{kg}^{-1}$ dry soil, ( $\left.\bigcirc\right) \mathrm{Hg}$-polluted soil bioremediation with MSR33 cells concentration of $6 \mathrm{~g}$ cells kg ${ }^{-1}$ dry soil plus thioglycolate $(5 \mathrm{mM}),(\boldsymbol{\nabla}) \mathrm{Hg}$-polluted soil bioremediation with MSR33 cells concentration of $6 \mathrm{~g}$ cells $\mathrm{kg}^{-1}$ dry soil plus cells re-inoculation at $48 \mathrm{~h}$. The assays were performed in duplicate; bars indicate the standard deviation.

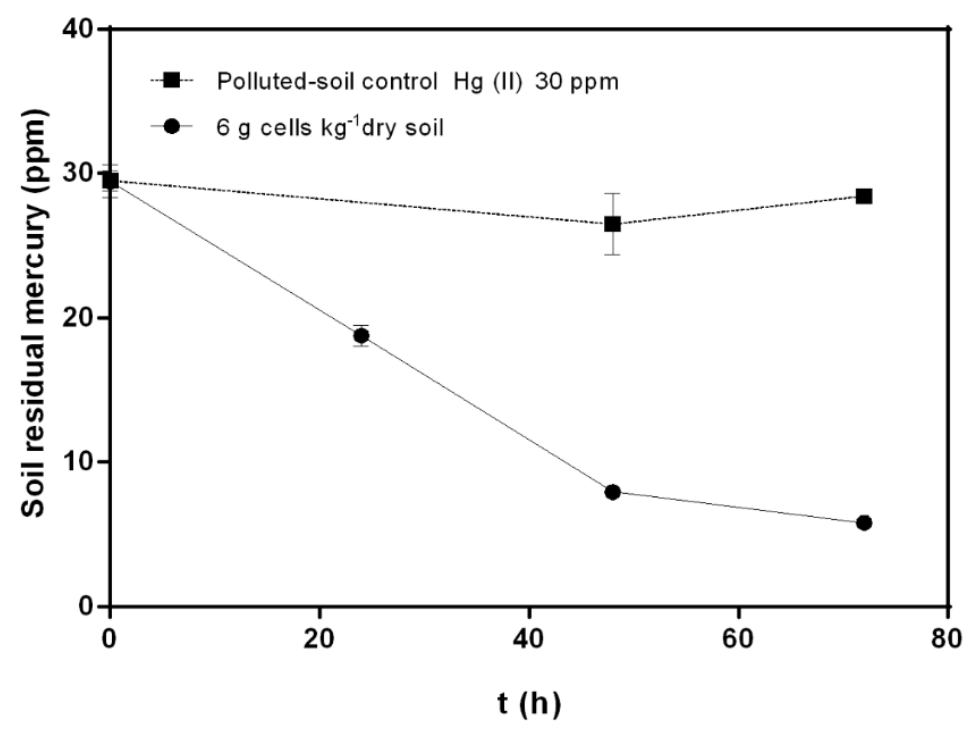

Figure 3. Effects of bioremediation by C. metallidurans MSR33 on agricultural soil polluted with mercury (II) (30 ppm) in rotary drum bioreactor. (匹) Hg-polluted control soil, $(\bullet) \mathrm{Hg}$-polluted soil bioremediation using $6 \mathrm{~g}$ cells $\mathrm{kg}^{-1}$ dry soil MSR33 cells concentration. The assays were performed in duplicate. Bars indicate the standard deviation. 


\subsection{Effects of Mercury and Mercury Bioremediation on Bacterial Communities of Agricultural Soils}

The effects of mercury and mercury bioremediation by strain MSR33 on bacterial communities in agricultural soils were evaluated by plate counting of total heterotrophic bacteria and mercury-tolerant bacteria. Mercury-tolerant bacteria (10 ppm) were isolated and identified by $16 \mathrm{~S}$ rRNA partial gene sequence analysis. The presence of the merG gene in the isolated strains was evaluated. The effects of mercury and mercury bioremediation on bacteria associated with the nitrogen cycle of agricultural soils and mercury tolerance were evaluated through the quantitative PCR of genes associated with nitrogen fixation, nitrification, strain MSR33 and plasmid pTP6.

Mercury-polluted soil showed a decrease in total heterotrophic bacteria and an increase in mercury-tolerant bacteria compared to non-polluted soil (Figure 4). The heterotrophic and mercurytolerant bacteria were increased by the bioremediation process.

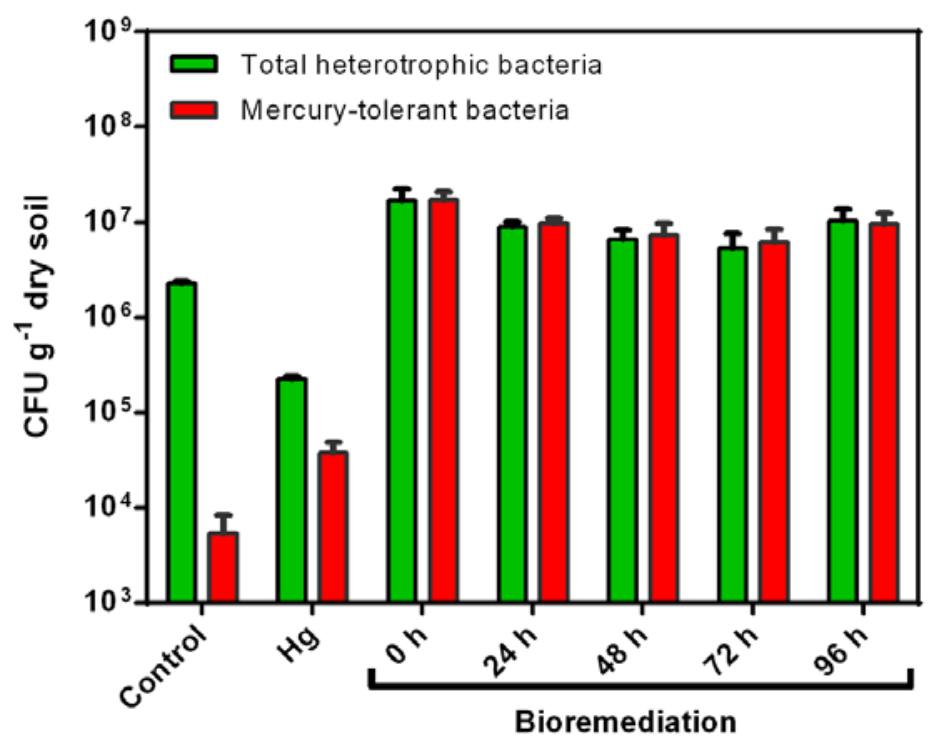

Figure 4. Effect of mercury and mercury bioremediation on the number of total heterotrophic and mercury-tolerant bacteria in agricultural soils. Total heterotrophic and mercury-tolerant bacteria were evaluated on TSA medium and TSA medium-plus mercury (10 ppm), respectively. Control: non-polluted agricultural soil; Hg: agricultural soil exposed to mercury (II) (20 ppm); Bioremediation: mercury-polluted agricultural soil bioremediated on rotary drum bioreactor by C. metallidurans strain MSR33 at different times. Green bars indicate total heterotrophic bacteria and red bars indicate mercury-tolerant bacteria. The bacterial count was performed in quintuplicate. Bars indicate the standard deviation.

For bacterial identification, comparative $16 \mathrm{~S}$ rRNA gene (400-700 pb) sequence analyses of the isolates were performed. The results indicated that strain SB1a belongs to the Glutamicibacter genus of the Actinobacteria phylum, showing 100\% 16S rRNA gene sequence similarity to the type strain Glutamicibacter arilaitensis Re117 ${ }^{\mathrm{T}}$. Strain SB1b was identified as a Bacillus member of the Firmicutes phylum, with $100 \% 16 \mathrm{~S}$ rRNA gene sequence similarity to the type strain Bacillus subterraneus COOI3B ${ }^{\mathrm{T}}$. The isolate SB2b was identified as a Planomicrobium strain of the Firmicutes phylum, showing $100 \%$ 16S rRNA gene sequence identity with the type strain Planomicrobium chinense DX3-12 ${ }^{\mathrm{T}}$. Strain SB2a was associated to the Bergeyella genus of the Bacteroidetes phylum, with 96\% $16 \mathrm{~S}$ rRNA gene sequence similarity with the type strain Bergeyella porcorum $1350-03^{\mathrm{T}}$. Strain SB3b belongs to Brevundimonas genus of the Proteobacteria phylum, possessing $100 \% 16 \mathrm{~S}$ rRNA gene sequence identity to the type strain Brevundimonas naejangsanensis BIO-TAS2-2 ${ }^{\mathrm{T}}$. The isolate SB4b belongs to the Ochrobactrum genus of the Proteobacteria phylum, with $100 \% 16 \mathrm{~S}$ rRNA gene sequence similarity to the type strain Ochrobactrum pituitosum CCUG $50899^{\mathrm{T}}$. The $16 \mathrm{~S}$ rRNA gene sequences of the isolated strains and other reported 
bacteria, including type strains from Glutamicibacter, Bacillus, Planomicrobium, Bergeyella, Brevundimonas and Ochrobactrum genera, were used to build a phylogenetic tree (Figure 5).

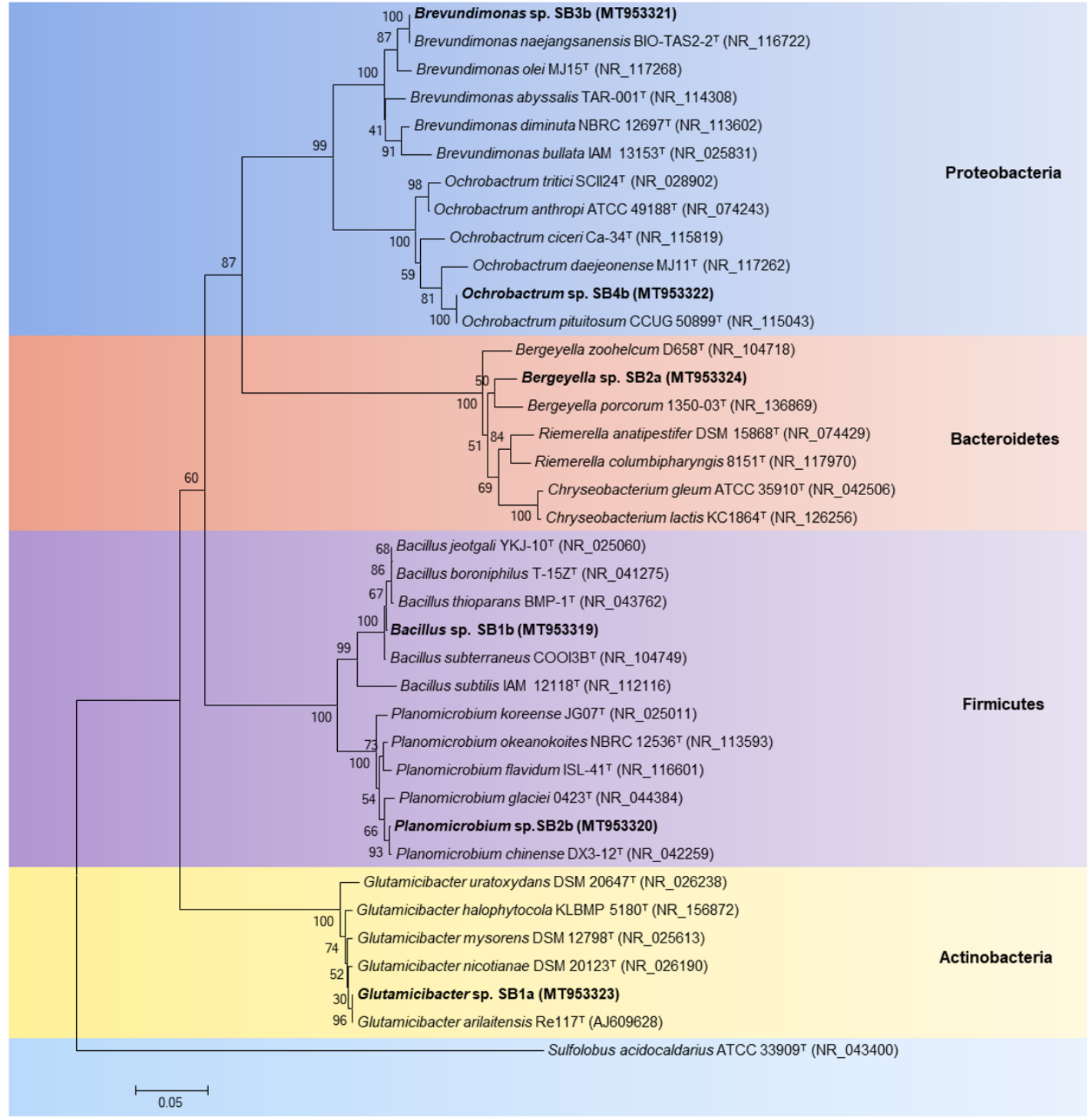

Figure 5. Identification by $16 \mathrm{~S}$ rRNA gene sequence analyses of mercury-tolerant bacterial strains from bioremediated agricultural soil. The phylogenetic tree was constructed using Neighbor-joining method. The tree has arbitrarily been rooted by the archaeon Sulfolobus acidocaldarius. Values of 1000 bootstrap are informed at the branching point. GenBank accession numbers of 16S rRNA sequences are indicated in parentheses. Scale bar represents 0.05 substitutions per nucleotide positions.

In order to determine if mercury tolerance of these strains may be associated to horizontal gene transfer of broad-spectrum mercury resistance genes from strain MSR33, the presence of the merG gene was evaluated by PCR in mercury-tolerant isolates (Figure 6).

The gram-positive strain Glutamicibacter sp. SB1a, and the gram-negative strains Breoundimonas sp. SB3b and Ochrobactrum sp. SB4b possess the mer $G$ gene. These results suggest the horizontal gene transfer of broad-spectrum mercury resistance genes from C. metallidurans strain MSR33 to indigenous soil bacteria during the bioremediation process.

To evaluate the effects of mercury and mercury bioremediation on the nitrogen cycle of agricultural soil, genes associated to nitrogen fixation (nifH) and nitrification ( $\mathrm{AOB}$ amoA) were studied by absolute qPCR in soil (Figure 7). 


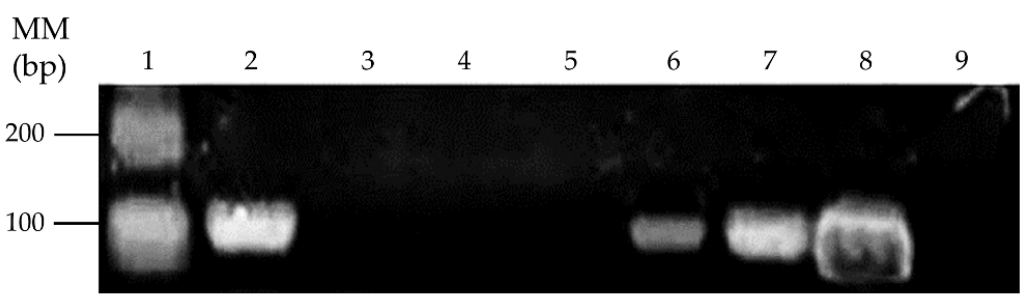

Figure 6. Detection of the merG gene in mercury-tolerant bacterial strains from bioremediated agricultural soil. Lane 1, Molecular mass marker 100 bp plus. Lanes 2-7, Mercury-tolerant bacterial strains SB1a, SB2a, SB1b, SB2b, SB3b, and SB4b. Lane 8, the merG gene positive control (C. metallidurans strain MSR33 genomic DNA). Lane 9, Negative control.
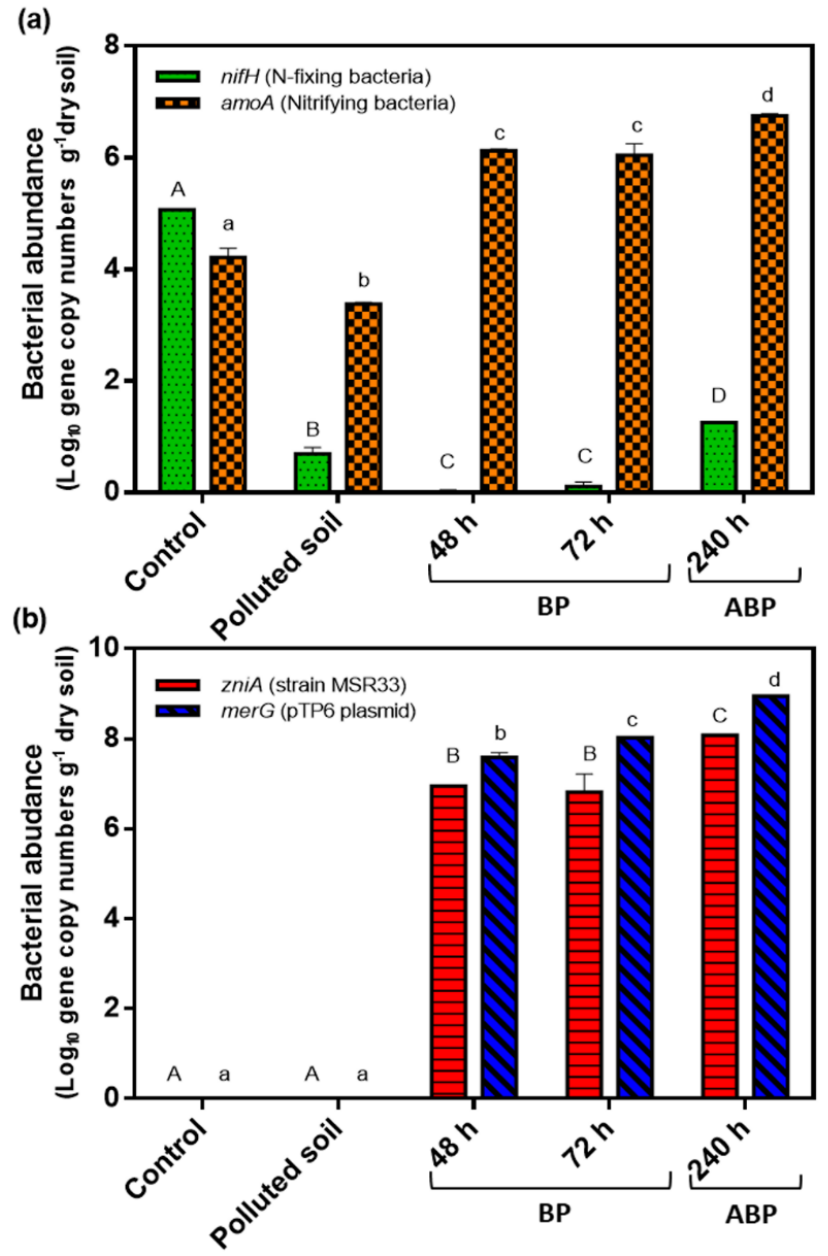

Figure 7. Effects of mercury (II) (20 ppm) and mercury bioremediation on gene copy numbers of nifH, $\mathrm{AOB}$ amoA, zniA, and merG in agricultural soils. (a), Copy numbers of nitrogen cycle genes (nifH and AOB amoA). (b), Copy numbers of strain MSR33 tracking zniA gene and of plasmid pTP6 tracking merG gene. Gene copy numbers were expressed in $\log _{10}$. Control: metagenomic DNA of non-polluted soil; Polluted soil: metagenomic DNA of mercury-polluted soil (exposed to mercury (II) (20 ppm) for 1 week; 48 and $72 \mathrm{~h}$ : metagenomic DNA of soil samples withdrawn from rotary drum bioreactor (RDB) during bioremediation process (BP); 240 h: metagenomic DNA of soil samples withdrawn from RDB 1 week after bioremediation processes (ABP). Assays were performed in triplicate; bars indicate the standard deviation. Significant differences were analysed by one-way ANOVA followed by LSD Fisher test. Means with different letters indicate significant differences $(p<0.05)$. Capital letters indicate significant differences for nifH (a) and zniA (b) genes, and lowercase letters indicate significant differences for AOB amo $A(\mathbf{a})$ and $\operatorname{merG}(\mathbf{b})$ genes. 
The presence of mercury in agricultural soils strongly decreased the copy number of the nifH gene ( 5 copies) compared to control soil $\left(1.14 \times 10^{5}\right.$ copies). During the bioremediation process (48 and $\left.72 \mathrm{~h}\right)$, a significant decrease in the nifH gene copies was observed. At $240 \mathrm{~h}$ after the bioremediation process, a significant increase in copy number of nifH gene was observed $\left(1 \times 10^{3}\right.$ copies $)$. Mercury pollution decreased the copy number of AOB amo $A$ gene in soils $\left(2.3 \times 10^{3}\right.$ copies $)$ compared to non-polluted control soil $\left(1.6 \times 10^{4}\right.$ copies) (Figure 7$)$. During the bioremediation process, a high increase in copy number of $\mathrm{AOB}$ amoA gene was observed $\left(1.3 \times 10^{6}\right.$ copies). The highest levels of the AOB amoA gene were observed at $240 \mathrm{~h}$ after the bioremediation process $\left(5.6 \times 10^{6}\right.$ copies $)$.

During the bioremediation process of mercury-polluted soils, strain MSR33 was tracked through qPCR analysis of the zniA gene. The zniA gene is present in a single copy in the chromid of strain MSR33 and encodes a heavy metal cation pump. The plasmid pTP6 was tracked using the merG gene. The broad-spectrum mercury resistance merG gene is present in a single copy in plasmid pTP6 and encodes a permease for phenylmercury. The copy number of zniA gene was detected only during the soil bioremediation at 48 and $72 \mathrm{~h}$ and after the bioremediation process $(240 \mathrm{~h})$. The zniA gene was not detected in non-polluted control soil and non-bioremediated mercury-polluted soil (Figure 7). No significant differences were observed between the copy number of the $z n i A$ gene during 48 and $72 \mathrm{~h}\left(8.7 \times 10^{6}\right.$ and $6.5 \times 10^{6}$ copies, respectively). A significant increase in the copy number of the $z n i A$ gene was observed at $240 \mathrm{~h}$ after the bioremediation process $\left(1.1 \times 10^{8}\right.$ copies $)$. The mer $G$ gene showed a similar pattern to the zniA gene. The merG gene was only detected during the soil bioremediation process, at 48 and $72 \mathrm{~h}$, and after the bioremediation process $(240 \mathrm{~h})$. The mer $\mathrm{G}$ gene was not observed in the non-polluted control soil and non-bioremediated mercury-polluted soil (Figure 7). High levels of the merG gene were observed during the bioremediation process (48 and $72 \mathrm{~h})\left(3.1 \times 10^{7}\right.$ and $1.0 \times 10^{8}$ copies, respectively) and after the bioremediation process $(240 \mathrm{~h})\left(8.7 \times 10^{8}\right.$ copies $)$.

\section{Discussion}

Bioremediation and phytoremediation are technologies of increasing application for the clean-up of polluted soils. Microbes play a crucial role in bioremediation and phytoremediation [60-63]. However, the bioremediation of mercury-polluted soil has been scarcely studied [31,41-43]. In this study, we established a novel ex situ bioremediation technology using bioaugmentation by $C$. metallidurans MSR33 in an RDB for mercury removal in polluted soils. Therefore, in this study, an acrylic RDB (20 L) with 8 internal lifters, equipped with a humidified air injection system and a gas trap for gaseous mercury, was designed and built (Figure 1). This bioremediation treatment was an effective technology for high mercury removal (up to $82 \%$ after $48 \mathrm{~h}$ ) in agricultural soils polluted with mercury II (20-30 ppm).

The bioremediation by bioaugmentation with strain MSR33 of mercury-polluted agricultural soils in the RDB showed high mercury removal under diverse conditions. However, in all assays, a residual mercury concentration was observed after the bioremediation processes. Residual mercury in soil can be attributed to the binding of non-bioavailable $\mathrm{Hg}$ (II) to the organic matter. Mercury (II) interacts strongly with sulfur ligands of the organic matter [17,18,22,30]. In this study, the addition of thioglycolate resulted in the highest mercury removal in soil. The addition of thioglycolate $(5 \mathrm{mM})$ increases mercury removal (10\%), reaching the lowest residual mercury content in soil ( $2.5 \mathrm{ppm})$. Thioglycolate increases the mercury bioavailability from soil organic matter through the formation of the dimercaptide RS-Hg-SR that is more susceptible to reduction [19,64]. Rojas et al. [19] reported the complete mercury removal by strain MSR33 of mercury-polluted aqueous solutions (20 and 30 ppm) in $2 \mathrm{~h}$, using $250 \mathrm{~mL}$ flasks (50 mL cellular suspension) and high aeration rate (6 vvm) in the presence of thioglycolate.

Interestingly, a faster mercury removal was observed by MSR33 inoculation with $6 \mathrm{~g} \mathrm{cells} \mathrm{\textrm {kg } ^ { - 1 }}$ dry soil compared with $3 \mathrm{~g}$ cells $\mathrm{kg}^{-1}$ dry soil in the first $48 \mathrm{~h}$, but both treatments reached similar mercury removal after $72 \mathrm{~h}$ (Figure 2). These results may indicate the dependence between the cellular concentration and mercury removal in the first $48 \mathrm{~h}$. Thereafter, a lower mercury bioavailability decreased 
its removal, reaching a similar mercury reduction with both cellular concentrations. Similar results were observed by bioremediation using Pseudomonas putida PpY101/pSR134 in mercury-polluted water, which showed a dependence between the cellular concentration and the mercury removal rate [39]. Aerobic mercury bioremediation in a bioreactor with strain MSR33 showed a fast mercury removal

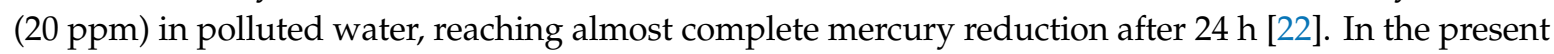
study, the re-inoculation of strain MSR33 was evaluated to rule out the potential inhibition of this strain and to increase the mercury removal during the bioremediation of mercury-polluted soil in the RDB. Additional cell re-inoculation at $48 \mathrm{~h}$ did not influence soil bioremediation, suggesting the dependency of strain MSR33 on mercury bioavailability for soil bioremediation.

Notably, a high mercury concentration (30 ppm) in soil did not negatively affect the removal of mercury by strain MSR33 (Figure 3). This result can be attributed to a higher mercury bioavailability that is susceptible to reduction by strain MSR33. In a previous study, we reported that strain MSR33 was capable of removing mercury (II) 24 ppm in polluted water [19]. However, mercury (II) 20 ppm inhibited the growth and respiratory rate of strain MSR33 in liquid medium under aerobic conditions; the inhibition was reversed after $5 \mathrm{~h}$ [22]. Mercury-polluted soil may dampen the harmful effects of high mercury concentration on the bioremediation by strain MSR33.

In this study, mercury (II) exposure reduced the number of total heterotrophic bacteria in agricultural soils, while an increase in Hg-tolerant bacteria was observed. These results indicate the susceptibility to mercury (II) of heterotrophic bacteria. The negative effects of mercury on bacteria have been widely described [17,19,65-68]. The pollution of mercury (4 weeks) changes the microbial community in agricultural soils, strongly decreasing bacteria of the Firmicutes phylum and increasing members of the Alphaproteobacteria class and the Planctomycetes phylum [13]. Short-term heavy metal pollution induces significant modifications in soil bacterial community structure [23]. The present study showed the presence of Hg-tolerant bacteria in non-polluted soil, whereas an increase of Hg-tolerant bacteria was observed 1 week after mercury pollution of the soil. The presence of bacteria with heavy metal tolerance in non-polluted soil has been reported, showing a significant increase of these bacteria in soils impacted with heavy metals [3]. Similarly, metagenomic analysis showed an increase of hydrocarbon-degrading bacteria in diesel-polluted soils [27]. During bioremediation, an increase of total heterotrophic and Hg-tolerant bacteria in agricultural soils was observed, which may be partly explained by the inoculation of strain MSR33 into the soil. Interestingly, bacterial abundance remained stable during $96 \mathrm{~h}$ of the bioremediation process.

In this report, mercury-resistant bacterial isolates from bioremediated mercury-polluted soils were identified as the gram-positive strains Glutamicibacter sp. SB1a, Bacillus sp. SB1b and Planomicrobium sp. SB2b, and the gram-negative strains Bergeyella sp. SB2a, Brevundimonas sp. SB3b and Ochrobactrum sp. SB4b (Figure 5). The isolation of mercury-tolerant bacteria (2-20 ppm) from diverse polluted environments have been described [69-73]. Our study is the first report describing mercury-resistant strains from the Glutamicibacter, Planomicrobium and Bergeyella genera. Nevertheless, heavy metal resistance in Glutamicibacter and Planomicrobium strains were described [74-76]. Mercury-tolerant Bacillus was isolated from mercury-contaminated soils, water, sediments, and High-Arctic snow and freshwater [63,69,71,73,77-79]. Mercury-tolerant Ochrobactrum strains were isolated from hydroelectric dam sediment and Porcellio scaber gut $[70,71]$. Mercury-tolerant strains of the Brevundimonas genus, including the mercury-resistant Brevundimonas sp. strains HgP1 and HgP2, were isolated from agricultural soil and gold mines [13,72]. In our study, selective pressure by mercury and the bioremediation process favored the increase of infrequent $\mathrm{Hg}$-tolerant bacteria. This is in accordance with an increase of hydrocarbon-degrading bacteria in the soil after hydrocarbon pollution and bioremediation reported by Fuentes et al. [27]. Further studies are required for a deeper understanding of the effects of mercury pollution and bioremediation on bacterial communities in agricultural soils.

The presence of the merG gene in native Hg-tolerant strains was observed in this report. Glutamicibacter sp. SB1a, Brevundimonas sp. SB3b, and Ochrobactrum sp. SB4b contain the merG gene (Figure 6). The merG gene encodes for a periplasmic protein involved in cell permeability of 
phenylmercury, which is part of the broad-spectrum mercury resistance and is present in a single copy in plasmid pTP6 [19]. The presence of the merG gene in the mer operon showed a lower frequency ( $1.8 \%$ in 272 bacterial and archaeal mer operons analysed) compared to other mer genes encoding narrow-spectrum $\mathrm{Hg}$ resistance such as the merA gene [80]. The presence of the mer $G$ gene in native bacteria suggests the horizontal gene transfer (HGT) of the plasmid pTP6 from strain MSR33 to native strains in soil. In our study, the results suggest that strain MSR33 acts as a mercury resistance gene donor to native gram-positive and gram-negative bacteria such as Glutamicibacter sp. SB1a (Actinobacteria), Brevundimonas sp. SB3b, and Ochrobactrum sp. SB4b (Proteobacteria), favoring a bioremediation process mediated by strain MSR33 and native bacteria adapted to mercury-polluted soil. Therefore, the presence of the plasmid pTP6 in native strains should be further studied. The HGT is an important mechanism for increasing the degradative traits of microbial communities [61]. The HGT results from conjugation, transformation, or transduction, wherein the conjugation is the most important mechanism [81]. Plasmid-mediated genetic variation enables bacteria to respond promptly to challenges, such as the presence of antibiotics, heavy metals, and xenobiotic compounds [82]. The plasmid pTP6 was captured from contaminated sediment slurry in River Nura (Kazakhstan) by Cupriavidus necator JMP228 [83]. The horizontal transfer of IncP-1 plasmids closely related to plasmid pTP6 from the Proteobacteria phylum to Actinobacteria, Firmicutes, and Bacteroidetes phyla has been reported [84,85]. Inter-gram plasmid transfer of IncP-1 is a frequent phenomenon in soil [86]. Plasmid-mediated bioaugmentation has been proven to be effective for the clean-up of soils contaminated with heavy metals and organic compounds $[87,88]$. The broad-spectrum mercury resistance genes are part of the transposon Tn50580 in plasmid pTP6 $[19,34,83]$. Therefore, a transposon-mediated transfer of mercury resistance genes from strain MSR33 to native bacteria may occur. The transposon-mediated in situ transfer of the mer genes from introduced microbes to autochthonous bacteria has been recently described as an innovative technology for bioremediation [89].

In this study, the effects of mercury pollution and bioremediation by strain MSR33 in an RDB on nitrogen cycle microorganisms in agricultural soils were determined (Figure 7). The copy number of nifH gene (nitrogen fixers) and AOB amoA (nitrifying bacteria) gene quantified in non-polluted agricultural soil in this study is similar to gene levels described for agricultural soils [6,90]. Mercury pollution caused a decrease of the nifH gene ( $\sim 4$ orders of magnitude) and the AOB amoA gene ( $\sim 1$ order of magnitude), indicating the susceptibility to mercury of nitrogen-fixing and nitrifying bacteria communities in the soils. Exposure to heavy metals including mercury and pesticides induces alterations in the bacterial communities of agricultural soils $[2,8,27,30,91]$. In contrast, no significant differences in copy number of $\mathrm{AOB}$ amo $A$ gene in soils after exposure to mercury (up to $200 \mathrm{ppm}$ ) have also been reported, however, the $\mathrm{AOB}$ amo $A$ gene was quantified eight weeks after the mercury pollution event [90].

The bioremediation by strain MSR33 of mercury-polluted soils in the RDB decreased the copy numbers of the nifH gene, whereas the $\mathrm{AOB}$ amo $A$ gene showed an increase during bioremediation, reaching even higher values than in non-polluted soil (Figure 7). This change in the microbial dynamics could be attributed to three factors: (i) mercury bioremediation process, (ii) increase of oxygen during the bioremediation, and (iii) the presence of exogenous nitrogen supplied by the GBC medium used for MSR33 growth. Firstly, it has been reported that bioremediation processes affect the dynamics of microbial communities [27,57]. Bioaugmentation by Pseudomonas sp. MHP41 of simazine-polluted agricultural soils changes the bacterial communities, increasing Acidobacteria and Planctomycetes phyla [57]. Hydrocarbon soil bioremediation showed changes in microbial community structure, observing a bloom of a specific bacterium present in low abundance before the pollution, and decreasing bacterial diversity and richness [27]. Secondly, in this study, the agricultural soil bioremediation process was performed in presence of oxygen in the RDB. Oxygen may damage the $\mathrm{Fe}-\mathrm{S}$ groups of the nitrogenase reductase enzyme, inhibiting nitrogen-fixing diazotrophic bacteria [92]. On the other side, the presence of oxygen favors nitrification and increases nitrifying bacteria in agricultural soils [93]. Finally, the observed changes in copy number of the nifH and AOB amoA 
genes may be associated to external nitrogen sources. The addition of MSR33 cells grown in GBC medium that contains $\mathrm{NH}_{4} \mathrm{Cl}$ could affect the copy number of the nifH and $\mathrm{AOB}$ amoA genes during the bioremediation process. The incorporation of nitrogen in soils affects the structure of nitrogen cycle microorganisms [2,6]. The addition of urea stimulates the nitrogen fixation (nifH), nitrification (AOB amoA) and denitrification (nirS, nirK) bacteria in Antarctic soils [94]. The application of urea and compost in agricultural soils decreases the nitrogen-fixing microorganisms and increases the number of nitrifying microorganisms [6].

Interestingly, significant differences in the nifH and the $\mathrm{AOB}$ amo $A$ genes levels were observed one week after bioremediation of mercury-polluted soils, showing an increase in the number of nitrogen-fixing and nitrifying bacteria (Figure 7). The copy number of the nifH gene showed a significant increase after bioremediation. The removal of mercury and the decrease in aeration could contribute to an increase of nitrogen-fixing bacteria, due to the absence of toxic effects caused by mercury and oxygen. The restoration of nitrogen-fixing bacterial populations could contribute to an increase in nitrifying bacteria, indicating the return of nitrogen cycle to natural conditions. These results indicate a positive effect of bioremediation of mercury-polluted agricultural soil on biological soil parameters associated with the nitrogen cycle. Nitrogen cycle-associated processes are performed by several microbial taxa. Within this study, only part of the microbial communities was evaluated. In this study, nitrifying archaea and denitrifying microorganisms were not studied, which may play an important role in nitrogen cycle of agricultural soils [2,5,6,8,22,95]. Further studies are required to understand the nitrogen cycle microbial dynamics during bioremediation by strain MSR33 of mercury-polluted agricultural soils.

This study showed that strain MSR33 inoculated during the bioremediation process was maintained during and after the treatment. An increase of the zniA (strain MSR33) and the merG (plasmid pTP6) genes at the end of the bioremediation process was observed, which is in agreement with the higher levels of Hg-tolerant bacteria (Figures 4 and 7). It is well known in bioremediation processes that after the addition of a single bacterium or bacterial consortium into the soil, their abundance in soil decrease after some weeks, concomitant with an increase of native bacterial taxa [27,96]. Notably, strain MSR33 showed an increase after bioremediation, suggesting its adaptation to the soil. The adaptation and colonization of $C$. metallidurans MSR33 in mercury-polluted soils support its use as a protective agent for soils exposed to heavy metal pollution.

Figure 8 illustrates the effects of mercury pollution and bioremediation in agricultural soils. Mercury pollution disturbed bacterial communities in agricultural soil, inhibiting the native bacteria and specifically nitrogen cycle microorganisms. During bioremediation using strain MSR33 of mercury-polluted agricultural soil in an RDB, a decrease of nitrogen-fixing bacteria and an increase of nitrifying bacteria were observed. Strain MSR33 transferred mercury resistance genes probably through the plasmid pTP6 conjugation to indigenous bacteria. Strain MSR33 and native Hg-tolerant bacteria removed the bioavailable mercury from the agricultural soil. After bioremediation, strain MSR33 was maintained and nitrogen-fixing microbial communities were restored in the bioremediated soil, establishing a new microbial communities' equilibrium.

Bioremediation by strain MSR33 in an RDB has a high potential for the treatment of soils polluted with heavy metals, such as mercury, cadmium, and copper, and persistent organic pollutants such as toluene $[19,22,36,37]$. This study suggests that bioremediation by bioaugmentation using bacteria (e.g., strain MSR33) in an RDB may be an attractive and innovative technology for the treatment of soils polluted with seed-coat dressing, pesticides, disinfectants, and pharmaceutical compounds, and soils impacted by mining towards a more sustainable development. 


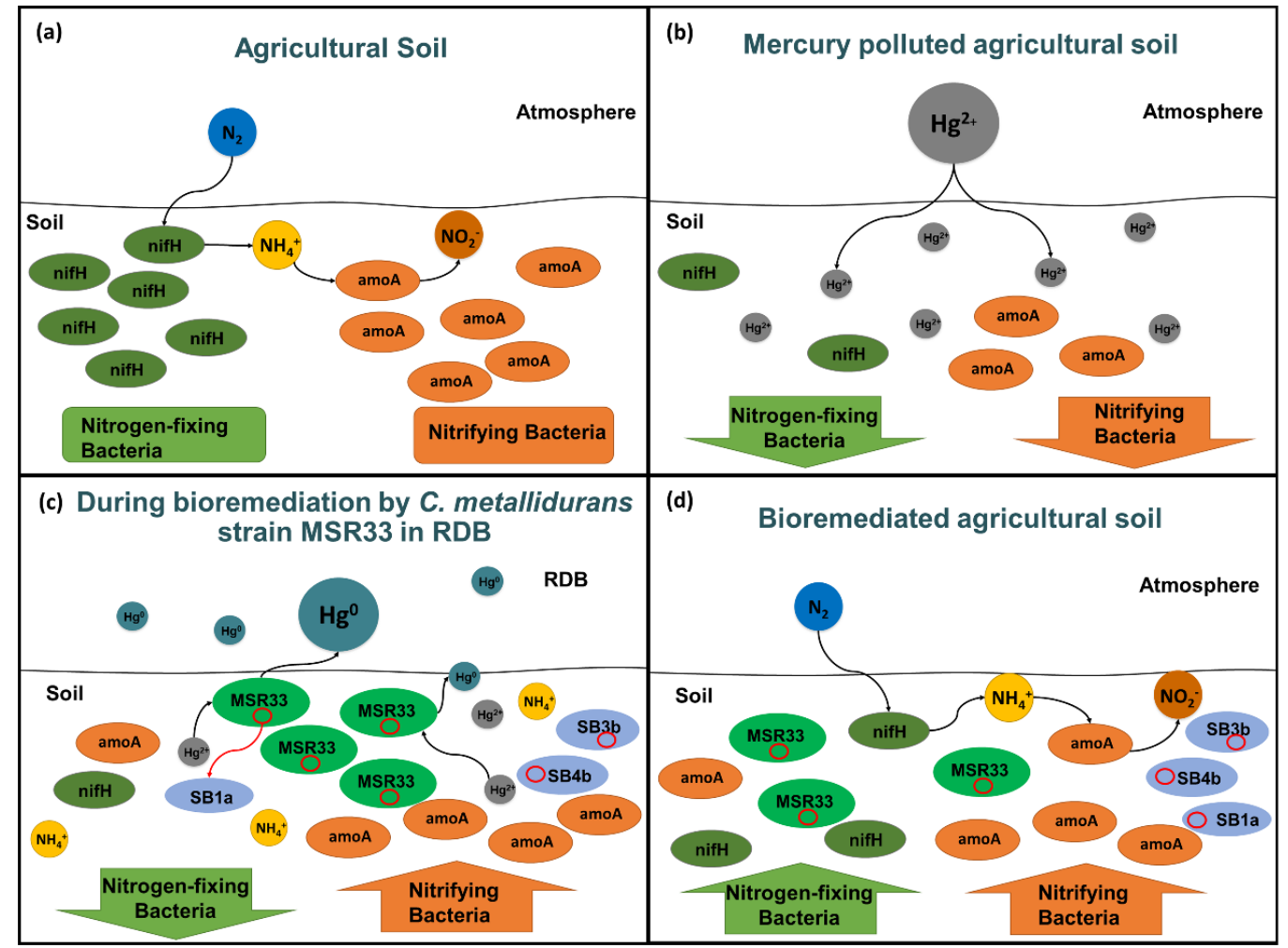

Figure 8. Overview of the effects of mercury and mercury bioremediation by C. metallidurans strain MSR33 of agricultural soil on nitrogen cycle microorganisms in rotary drum bioreactor (RDB). (a), Balance between nitrogen-fixing and nitrifying microorganisms in agricultural soil. (b), Inhibition of nitrogen-fixing and nitrifying microorganisms in agricultural soil exposed to mercury. (c), Imbalance between nitrogen-fixing and nitrifying microorganisms during mercury-polluted agricultural soil bioremediation by C. metallidurans strain MSR33 in RDB. (d), Re-establishment of nitrogen-fixing and nitrifying bacterial communities in mercury-remediated agricultural soil by $C$. metallidurans strain MSR33 in RDB. The plasmid pTP6 is represented in red circles on (c) and (d).

\section{Conclusions}

An innovative ex situ bioremediation process by C. metallidurans strain MSR33 of an agricultural soil polluted with $\mathrm{Hg}$ (II) (20 and $30 \mathrm{ppm}$ ) in a custom-made RDB was established, removing $82 \%$ of mercury in the presence of thioglycolate and $70 \%$ in absence of this agent. Mercury pollution affected soil nitrogen cycle bacteria, decreasing nitrogen-fixing bacteria and nitrifying bacteria. Specially nitrogen-fixing bacteria were highly sensitive to mercury pollution. During the bioremediation by strain MSR33 of mercury-polluted agricultural soil in the RDB, changes in nitrogen cycle communities were observed, increasing the nitrifying bacteria, but decreasing the nitrogen-fixing bacteria. During the bioremediation, strain MSR33 probably transfered the mercury resistance merG gene through the plasmid pTP6 into indigenous gram-positive and gram-negative bacteria, increasing their mercury resistance.

The bioremediation of mercury-polluted agricultural soil restored the nitrogen cycle, showing an increase of the nitrogen-fixing bacteria and the nitrifying bacteria. After bioremediation, strain MSR33 and native mercury-tolerant bacteria showed high levels in soil and may act as bioremediation catalysts in future mercury-pollution events.

Author Contributions: G.B., J.C.G., and M.S. conceived and designed the experiments; G.B. and P.V.-C. performed the experiments; G.B., P.V.-C., J.C.G., and M.S. analysed the data; J.C.G. and M.S. contributed reagents, materials, and analysis tools; G.B., P.V.-C., J.C.G. and M.S. wrote the paper. All authors have read and agreed to the published version of the manuscript. 
Funding: This research was funded by PhD Conicyt, PUCV and USM (G.B., P.V.-C.) fellowships, ANID PIA Ring Genomics and Applied Microbiology for Bioremediation and Bioproducts (GAMBIO) ACT172128 Chile (M.S., G.B., P.V.-C.), Fondequip EQM 170194 (M.S., G.B.), Fondecyt 1200756 (M.S., P.V.-C.), PIIC USM (G.B., P.V.-C.), and USM (M.S., P.V.-C., G.B.) grants.

Acknowledgments: The authors thank Luis Rojas for providing the primers for the $z$ niA and merG genes amplification, and Julieta Orlando for proving Escherichia coli clone AOB amoA. The authors acknowledge the Fermentation Laboratory, School of Biochemical Engineering, Pontificia Universidad Católica de Valparaíso.

Conflicts of Interest: The authors declare no conflict of interest.

\section{References}

1. Abhilash, P.C.; Kant Dubey, R.; Tripathi, V.; Gupta, V.K.; Singh, H.B. Plant growth promoting microorganisms for environmental sustainability. Trends Biotechnol. 2016, 34, 847-850. [CrossRef] [PubMed]

2. Hernández, M.; Jia, Z.; Conrad, R.; Seeger, M. Simazine application inhibits nitrification and changes the ammonia-oxidizing bacterial communities in a fertilized agricultural soil. FEMS Microbiol. Ecol. 2011, 78, 511-519. [CrossRef] [PubMed]

3. Altimira, F.; Yáñez, C.; Bravo, G.; González, M.; Rojas, L.A.; Seeger, M. Characterization of copper-resistant bacteria and bacterial communities from copper-polluted agricultural soils of Central Chile. BMC Microbiol. 2012, 12, 193. [CrossRef] [PubMed]

4. Seshadri, B.; Bolan, N.; Naidu, R. Rhizosphere-induced heavy metal(loid) transformation in relation to bioavailability and remediation. J. Soil Sci. Plant Nutr. 2015, 15, 524-548. [CrossRef]

5. Tosi, M.; Brown, S.; Ferrari Machado, P.; Wagner-Riddle, C.; Dunfield, K. Short-term response of soil N-cycling genes and transcripts to fertilization with nitrification and urease inhibitors, and relationship with field-scale $\mathrm{N}_{2} \mathrm{O}$ emissions. Soil Biol. Biochem. 2020, 142, 107703. [CrossRef]

6. Hai, B.; Diallo, N.H.; Sall, S.; Haesler, F.; Schauss, K.; Bonzi, M.; Assigbetse, K.; Chotte, J.-L.; Munch, J.C.; Schloter, M. Quantification of key genes steering the microbial nitrogen cycle in the rhizosphere of sorghum cultivars in tropical agroecosystems. Appl. Environ. Microbiol. 2009, 75, 4993-5000. [CrossRef]

7. Jacoby, R.; Peukert, M.; Succurro, A.; Koprivova, A.; Kopriva, S. The role of soil microorganisms in plant mineral nutrition-Current knowledge and future directions. Front. Plant Sci. 2017, 8, 1617. [CrossRef]

8. Rütting, T.; Aronsson, H.; Delin, S. Efficient use of nitrogen in agriculture. Nutr. Cycl. Agroecosyst. 2018, 110, 1-5. [CrossRef]

9. Filip, Z. International approach to assessing soil quality by ecologically-related biological parameters. Agric. Ecosyst. Environ. 2002, 88, 169-174. [CrossRef]

10. Orlando, J.; Alfaro, M.; Bravo, L.; Guevara, R.; Carú, M. Bacterial diversity and occurrence of ammonia-oxidizing bacteria in the Atacama desert soil during a 'desert bloom' event. Soil Biol. Biochem. 2010, 42, 1183-1188. [CrossRef]

11. Menéndez, E.; Paço, A. Is the application of plant probiotic bacterial consortia always beneficial for plants? exploring synergies between rhizobial and non-rhizobial bacteria and their effects on agro-economically valuable crops. Life 2020, 10, 24. [CrossRef]

12. Mao, Y.; Yannarell, A.C.; Mackie, R.I. Changes in N-transforming Archaea and Bacteria in soil during the establishment of bioenergy crops. PLoS ONE 2011, 6, e24750. [CrossRef] [PubMed]

13. Salam, L.N.; Shomope, H.; Ummi, Z.; Bukar, F. Mercury contamination imposes structural shift on the microbial community of an agricultural soil. Bull. Natl. Res. Cent. 2019, 43, 163. [CrossRef]

14. Patra, M.; Sharma, A. Mercury toxicity in plants. Bot. Rev. 2000, 66, 379-422. [CrossRef]

15. Streets, D.G.; Horowitz, H.M.; Jacob, D.J.; Lu, Z.; Levin, L.; Ter Schure, A.F.H.; Sunderland, E.M. Total mercury released to the environment by human activities. Environ. Sci. Technol. 2017, 51, 5969-5977. [CrossRef] [PubMed]

16. Yang, L.; Zhang, Y.; Wang, F.; Luo, Z.; Guo, S.; Strähle, U. Toxicity of mercury: Molecular evidence. Chemosphere 2020, 245, 125586. [CrossRef] [PubMed]

17. Tagliafierro, L.; Officioso, A.; Sorbo, S.; Basile, A.; Manna, C. The protective role of olive oil hydroxytyrosol against oxidative alterations induced by mercury in human erythrocytes. Food Chem. Toxicol. 2015, 82, 59-63. [CrossRef]

18. Spiller, H.A. Rethinking mercury: The role of selenium in the pathophysiology of mercury toxicity. Clin. Toxicol. 2017, 56, 313-326. [CrossRef]

19. Rojas, L.A.; Yañez, C.; González, M.; Lobos, S.; Smalla, K.; Seeger, M. Characterization of the metabolically modified heavy metal-resistant Cupriavidus metallidurans strain MSR33 generated for mercury bioremediation. PLoS ONE 2011, 6, e17555. [CrossRef] 
20. Gómez-Sagasti, M.; Marino, D. PGPRs and nitrogen-fixing legumes: A perfect team for efficient Cd phytoremediation? Front. Plant Sci. 2015, 6, 1-9. [CrossRef]

21. Ojuederie, O.; Babalola, O. Microbial and plant-assisted bioremediation of heavy metal polluted environments: A review. Int. J. Environ. Res. Public Health 2017, 14, 1504. [CrossRef] [PubMed]

22. Bravo, G.; Vega-Celedón, P.; Gentina, J.C.; Seeger, M. Effects of mercury II on Cupriavidus metallidurans strain MSR33 during mercury bioremediation under aerobic and anaerobic conditions. Processes 2020, 8, 893. [CrossRef]

23. Ranjard, L.; Lignier, L.; Chaussod, R. Cumulative effects of short-term polymetal contamination on soil bacterial community structure. Appl. Environ. Microbiol. 2006, 72, 1684-1687. [CrossRef] [PubMed]

24. Yang, J.; Li, G.; Bishopp, A.; Heenatigala, P.P.M.; Hu, S.; Chen, Y.; Wu, Z.; Kumar, S.; Duan, P.; Yao, L.; et al. A comparison of growth on mercuric chloride for three Lemnaceae species reveals differences in growth dynamics that effect their suitability for use in either monitoring or remediating ecosystems contaminated with mercury. Front. Chem. 2018, 6, 212. [CrossRef]

25. Hernández, M.; Morgante, V.; Ávila, M.; Villalobos, P.; Millares, P.; González, M.; Seeger, M. Novel s-triazine-degrading bacteria isolated from agricultural soils of Central Chile for herbicide bioremediation. Electron. J. Biotechnol. 2008, 11, 5-6. [CrossRef]

26. Seeger, M.; Hernández, M.; Mendez, V.; Ponce, B.; Córdova, M.; González, M. Bacterial degradation and bioremediation of chlorinated herbicides and biphenyls. J. Soil Sci. Plant Nutr. 2010, 10, 320-332. [CrossRef]

27. Fuentes, S.; Barra, B.; Caporaso, J.G.; Seeger, M. From rare to dominant: A fine-tuned soil bacterial bloom during petroleum hydrocarbon bioremediation. Appl. Environ. Microbiol. 2015, 82, 888-896. [CrossRef]

28. Orellana, R.; Macaya, C.; Bravo, G.; Dorochesi, F.; Cumsille, A.; Valencia, R.; Rojas, C.; Seeger, M. Living at the frontiers of life: Extremophiles in Chile and their potential for bioremediation. Front. Microbiol. 2018, 9 , 2309. [CrossRef]

29. Deckwer, W.-D.; Becker, F.U.; Ledakowicz, S.; Wagner-Döbler, I. Microbial removal of ionic mercury in a three-phase fluidized bed reactor. Environ. Sci. Technol. 2004, 38, 1858-1865. [CrossRef]

30. Mahbub, K.; Krishnan, K.; Megharaj, M.; Naidu, R. Bioremediation potential of a highly mercury resistant bacterial strain Sphingobium SA2 isolated from contaminated soil. Chemosphere 2016, 144, 330-337. [CrossRef]

31. McCarthy, D.; Edwards, G.C.; Gustin, M.S.; Care, A.; Miller, M.B.; Sunna, A. An innovative approach to bioremediation of mercury contaminated soils from industrial mining operations. Chemosphere 2017, 184, 694-699. [CrossRef] [PubMed]

32. Wang, X.; He, Z.; Luo, H.; Zhang, M.; Zhang, D.; Pan, X.; Gadd, G.M. Multiple-pathway remediation of mercury contamination by a versatile selenite-reducing bacterium. Sci. Total Environ. 2018, 615, 615-623. [CrossRef]

33. Dash, H.R.; Das, S. Bioremediation of mercury and the importance of bacterial mer genes. Int. Biodeterior. Biodegrad. 2012, 75, 207-213. [CrossRef]

34. Millacura, F.A.; Janssen, P.J.; Monsieurs, P.; Janssen, A.; Provoost, A.; Van Houdt, R.; Rojas, L.A. Unintentional genomic changes endow Cupriavidus metallidurans with an augmented heavy-metal resistance. Genes 2018, 9 , 551. [CrossRef] [PubMed]

35. Montero-Silva, F.; Durán, N.; Seeger, M. Synthesis of extracellular gold nanoparticles using Cupriavidus metallidurans CH34 cells. IET Nanobiotechnol. 2018, 12, 40-46. [CrossRef]

36. Espinoza-Tofalos, A.; Daghio, M.; González, M.; Papacchini, M.; Franzetti, A.; Seeger, M. Toluene degradation by Cupriavidus metallidurans $\mathrm{CH} 34$ in nitrate-reducing conditions and in bioelectrochemical systems. FEMS Microbiol. Lett. 2018, 365, fny119. [CrossRef]

37. Alviz-Gazitua, P.; Fuentes-Alburquenque, S.; Rojas, L.A.; Turner, R.; Guiliani, N.; Seeger, M. The response of Cupriavidus metallidurans $\mathrm{CH} 34$ to cadmium involves inhibition of the initiation of biofilm formation, decrease in intracellular c-di-GMP levels, and a novel metal regulated phosphodiesterase. Front. Microbiol. 2019, 10, 1499. [CrossRef]

38. Seeger, M.; Rojas, L.; González, M.; Yáñez, C. Recombinant Bacterium Capable of Removing Mercury (Ii) Species, Cadmium (Ii) And Copper (Ii) In Presence of Other Heavy Metals from Polluted Sites, Product for The Bioremediation, Process of Obtaining the Product and Method of Bioremediation. U.S. Patent 8,846,376B2, 30 September 2014.

39. Okino, S.; Iwasaki, K.; Yagi, O.; Tanaka, H. Development of a biological mercury removal-recovery system. Biotechnol. Lett. 2000, 22, 783-788. [CrossRef] 
40. Głuszcz, P.; Petera, J.; Ledakowicz, S. Mathematical modeling of the integrated process of mercury bioremediation in the industrial bioreactor. Bioproc. Biosyst. Eng. 2010, 34, 275-285. [CrossRef]

41. Chang, J.; Duan, Y.; Dong, J.; Shen, S.; Si, G.; He, F.; Yang, Q.; Chen, J. Bioremediation of Hg-contaminated soil by combining a novel Hg-volatilizing Lecythophora sp. fungus, DC-F1, with biochar: Performance and the response of soil fungal community. Sci. Total Environ. 2019, 671, 676-684. [CrossRef]

42. Voijant, B.T.; Rozaimah, S.S.A.; Basri, H.; Idris, M.; Anuar, N.; Mukhlisin, M. A review on heavy metals (As, $\mathrm{Pb}$, and $\mathrm{Hg}$ ) uptake by plants through phytoremediation. Int. J. Chem. Eng. 2011, 2011, 1-31. [CrossRef]

43. Zgorelec, Z.; Bilandzija, N.; Knez, K.; Galic, M.; Zuz, S. Cadmium and mercury phytostabilization from soil using Miscanthus $\times$ giganteus. Sci. Rep. 2020, 10, 6685. [CrossRef] [PubMed]

44. Gray, M.R.; Banerjee, D.K.; Fedorak, P.M.; Hashimoto, A.; Masliyah, J.H.; Pickard, M.A. Biological remediation of anthracene-contaminated soil in rotating bioreactors. Appl. Microbiol. Biot. 1994, 40, 933-940. [CrossRef]

45. Banerjee, D.K.; Fedorak, P.M.; Hashimoto, A.; Masliyah, J.H.; Pickard, M.A.; Gray, M.R. Monitoring the biological treatment of anthracene-contaminated soil in a rotating-drum bioreactor. Appl. Microbiol. Biotechnol. 1995, 43, 521-528. [CrossRef]

46. Pinelli, D.; Fava, F.; Nocentini, M.; Pasquali, G. Bioremediation of a polycyclic aromatic hydrocarboncontaminated soil by using different aerobic batch bioreactor systems. Soil Sediment. Contam. 1997, 6, 243-256. [CrossRef]

47. Woo, S.H.; Park, J.M. Evaluation of drum bioreactor performance used for decontamination of soil polluted with polycyclic aromatic hydrocarbons. J. Chem. Technol. Biotechnol. 1999, 74, 937-944. [CrossRef]

48. Hardin, M.T.; Howes, T.; Mitchell, D.A. Mass transfer correlations for rotating drum bioreactors. J. Biotechnol. 2002, 97, 89-101. [CrossRef]

49. Barrera-Cortés, J.; Manilla-Pérez, E.; Poggi-Varaldo, H.M. Oxygen transfer to slurries treated in a rotating drum operated at atmospheric pressure. Bioproc. Biosyst. Eng. 2006, 29, 391-398. [CrossRef]

50. Rodríguez-Meza, M.A.; Chávez-Gómez, B.; Poggi-Varaldo, H.M.; Ríos-Leal, E.; Barrera-Cortés, J. Design of a new rotating drum bioreactor operated at atmospheric pressure on the bioremediation of a polluted soil. Bioproc. Biosyst. Eng. 2009, 33, 573-582. [CrossRef]

51. Jaramillo, A.C.; Cobas, M.; Hormaza, A.; Sanromá, M.A. Degradation of adsorbed azo dye by solid-state fermentation: Improvement of culture conditions, a kinetic study, and rotating drum bioreactor performance. Water Air Soil Pollut. 2017, 228, 205. [CrossRef]

52. Jin, J.; Liu, G.; Shi, S.; Cong, W. Studies on the performance of a rotating drum bioreactor for bioleaching processes-Oxygen transfer, solids distribution and power consumption. Hydrometallurgy 2010, 103, 30-34. [CrossRef]

53. Weisburg, W.G.; Barns, S.M.; Pelletier, D.A.; Lane, D.J. 16 S ribosomal DNA amplification for phylogenetic study. J. Bacteriol. 1991, 173, 697-703. [CrossRef] [PubMed]

54. Rösch, C.; Mergel, A.; Bothe, H. Biodiversity of denitrifying and dinitrogen-fixing bacteria in an acid forest soil. Appl. Environ. Microbiol. 2002, 68, 3818-3829. [CrossRef]

55. Rotthauwe, J.H.; Witzel, K.P.; Liesack, W. The ammonia monooxygenase structural gene amoA as a functional marker: Molecular fine-scale analysis of natural ammonia-oxidizing populations. Appl. Environ. Microbiol. 1997, 63, 4704-4712. [CrossRef] [PubMed]

56. AOAC Official Method 977.15 Mercury in Fish Alternative Flameless Atomic Absorption Spectrophotometric Method. First Action 1977 Final Action 1978. Available online: http://www.aoacofficialmethod.org/index. php?main_page=product_info\&cPath=1\&products_id=2383 (accessed on 14 November 2020).

57. Morgante, V.; López-López, A.; Flores, C.; González, M.; González, B.; Vásquez, V.; Rossello-Mora, R.; Seeger, M. Bioaugmentation with Pseudomonas sp. strain MHP41 promotes simazine attenuation and bacterial community changes in agricultural soils. FEMS Microbiol. Ecol. 2010, 71, 114-126. [CrossRef] [PubMed]

58. Tamura, K.; Peterson, D.; Peterson, N.; Stecher, G.; Nei, M.; Kumar, S. MEGA5: Molecular evolutionary genetics analysis using maximum likelihood, evolutionary distance, and maximum parsimony methods. Mol. Biol. Evol. 2011, 28, 2731-2739. [CrossRef]

59. Brankatschk, R.; Bodenhausen, N.; Zeyer, J.; Bürgmann, H. Simple absolute quantification method correcting for quantitative PCR efficiency variations for microbial community samples. Appl. Environ. Microbiol. 2012, 78, 4481-4489. [CrossRef]

60. Fuentes, S.; Méndez, V.; Aguila, P.; Seeger, M. Bioremediation of petroleum hydrocarbons: Catabolic genes, microbial communities, and applications. Appl. Microbiol. Biotechnol. 2014, 98, 4781-4789. [CrossRef] 
61. Thijs, S.; Sillen, W.; Rineau, F.; Weyens, N.; Vangronsveld, J. Towards an enhanced understanding of plant-microbiome interactions to improve phytoremediation: Engineering the metaorganism. Front. Microbiol. 2016, 16, 341. [CrossRef]

62. Thijs, S.; Sillen, W.; Weyens, N.; Vangronsveld, J. Phytoremediation: State-of-the-art and a key role for the plant microbiome in future trends and research prospects. Int. J. Phytoremediat. 2017, 19, 23-38. [CrossRef]

63. Mariano, C.; Mello, I.S.; Barros, B.M.; da Silva, G.F.; Terezo, A.J.; Soares, M.A. Mercury alters the rhizobacterial community in Brazilian wetlands and it can be bioremediated by the plant-bacteria association. Environ. Sci. Pollut. Res. Int. 2020, 27, 13550-13564. [CrossRef] [PubMed]

64. Wang, L.; Hou, D.; Cao, Y.; Sik Ok, Y.; Tack, F.M.; Rinklebe, J.; O'Connor, D. Remediation of mercury contaminated soil, water, and air: A review of emerging materials and innovative technologies. Environ. Int. 2020, 134, 105281. [CrossRef] [PubMed]

65. Asztalos, E.; Sipka, G.; Kis, M.; Trotta, M.; Maróti, P. The reaction center is the sensitive target of the mercury (II) ion in intact cells of photosynthetic bacteria. Photosynth. Res. 2012, 112, 129-140. [CrossRef] [PubMed]

66. Branco, V.; Ramos, P.; Canario, J.; Lu, J.; Holmgren, A.; Carvalho, C. Biomarkers of adverse response to mercury: Histopathology versus thioredoxin reductase activity. J. Biomed. Biotechnol. 2012, 2012, 1-9. [CrossRef]

67. Wang, Y.; Robison, T.; Wiatrowski, H. The impact of ionic mercury on antioxidant defenses in two mercury-sensitive anaerobic bacteria. BioMetals 2013, 26, 1023-1031. [CrossRef]

68. Pepi, M.; Lobianco, A.; Renzi, M.; Perra, G.; Bernardini, E.; Marvasi, M.; Gasperini, S.; Volterrani, M.; Franchi, E.; Heipieper, H.J.; et al. Two naphthalene degrading bacteria belonging to the genera Paenibacillus and Pseudomonas isolated from a highly polluted lagoon perform different sensitivities to the organic and heavy metal contaminants. Extremophiles 2009, 13, 839-848. [CrossRef]

69. Rasmussen, L.D.; Zawadsky, C.; Binnerup, S.J.; Øregaard, G.; Sørensen, S.J.; Kroer, N. Cultivation of hard-to-culture subsurface mercury-resistant bacteria and discovery of new merA gene sequences. Appl. Environ. Microbiol. 2008, 74, 3795-3803. [CrossRef]

70. Lapanje, A.; Zrimec, A.; Drobne, D.; Rupnik, M. Long-term Hg pollution-induced structural shifts of bacterial community in the terrestrial isopod (Porcellio scaber) gut. Environ. Pollut. 2010, 158, 3186-3193. [CrossRef]

71. François, F.; Lombard, C.; Guigner, J.M.; Soreau, P.; Brian-Jaisson, F.; Martino, G.; Vandervennet, M.; Garcia, D.; Molinier, A.L.; Pignol, D.; et al. Isolation and characterization of environmental bacteria capable of extracellular biosorption of mercury. Appl. Environ. Microbiol. 2012, 78, 1097-1106. [CrossRef]

72. Chasanah, U.; Nuraini, Y.; Handayanto, E. The potential of mercury-resistant bacteria isolated from small-scale gold mine tailings for accumulation of mercury. Ecol. Eng. 2018, 19, 236-245. [CrossRef]

73. Naguib, M.M.; Khairalla, A.S.; El-Gendy, A.O.; Elkhatib, W.F. Isolation and characterization of mercury-resistant bacteria from wastewater sources in Egypt. Can. J. Microbiol. 2019, 65, 308-321. [CrossRef] [PubMed]

74. Das, R.; Tiwary, B.N. Isolation of a novel strain of Planomicrobium chinense from diesel contaminated soil of tropical environment. J. Basic Microbiol. 2013, 53, 723-732. [CrossRef] [PubMed]

75. Duraisamy, P.; Sekar, J.; Arunkumar, A.D.; Ramalingam, P.V. Kinetics of phenol biodegradation by heavy metal tolerant rhizobacteria Glutamicibacter nicotianae MSSRFPD35 from distillery effluent contaminated soils. Front. Microbiol. 2020, 11, 1573. [CrossRef] [PubMed]

76. Santos, R.G.; Hurtado, R.; Gomes, L.G.R.; Profeta, R.; Rifici, C.; Attili, A.R.; Spier, S.J.; Giuseppe, M.; Morais-Rodrigues, F.; Gomide, A.C.P.; et al. Complete genome analysis of Glutamicibacter creatinolyticus from mare abscess and comparative genomics provide insight of diversity and adaptation for Glutamicibacter. Gene 2020, 741, 144566. [CrossRef] [PubMed]

77. Møller, A.K.; Barkay, T.; Al-Soud, W.A.; Sørensen, S.J.; Skov, H.; Kroer, N. Diversity and characterization of mercury-resistant bacteria in snow, freshwater and sea-ice brine from the High Arctic. FEMS Microbiol. Ecol. 2011, 75, 390-401. [CrossRef] [PubMed]

78. Cruz-Medina, J.A.; Enriquez, J.; Cruz, A.; Garcia, R.; Solis, S.; Hernandez, G.; Jones, G.H.; Campos-Guillen, J. Isolation and characterization of mercury resistant Bacillus sp. from soils with an extensive history as substrates for mercury extraction in Mexico. Geomicrobiol. J. 2013, 30, 454-461. [CrossRef]

79. Figueiredo, N.L.; Areias, A.; Mendes, R.; Canário, J.; Duarte, A.; Carvalho, C. Mercury-resistant bacteria from salt marsh of Tagus estuary: The influence of plants presence and mercury contamination levels. J. Toxicol. Environ. 2014, 77, 959-971. [CrossRef]

80. Boyd, E.; Barkay, T. The mercury resistance operon: From an origin in a geothermal environment to an efficient detoxification machine. Front. Microbiol. 2012, 3, 349. [CrossRef] 
81. Smalla, K.; Jechalke, S.; Top, E.M. Plasmid detection, characterization and ecology. Microbiol. Spectr. 2015, 3, 1. [CrossRef]

82. Heuer, H.; Smalla, K. Plasmids foster diversification and adaptation of bacterial populations in soil. FEMS Microbiol. Rev. 2012, 6, 1083-1104. [CrossRef]

83. Smalla, K.; Haines, A.S.; Jones, K.; Krogerrecklenfort, E.; Heuer, H.; Schloter, M.; Thomas, C.M. Increased abundance of IncP-1 $\beta$ plasmids and mercury resistance genes in mercury polluted river sediments-first discovery of IncP-1 $\beta$ plasmids with a complex mer transposon as sole accessory element. Appl. Environ. Microbiol. 2006, 72, 7253. [CrossRef] [PubMed]

84. Musovic, S.; Oregaard, G.; Kroer, N.; Sørensen, S.J. Cultivation-independent examination of horizontal transfer and host range of an IncP-1 plasmid among gram-positive and gram-negative bacteria indigenous to the barley rhizosphere. Appl. Environ. Microbiol. 2006, 80, 6687-6692. [CrossRef] [PubMed]

85. Shintani, M.; Matsui, K.; Inoue, J.; Hosoyama, A.; Ohji, S.; Yamazoe, A.; Nojiri, H.; Kimbara, K.; Ohkuma, M. Single-cell analyses revealed transfer ranges of IncP-1, IncP-7, and IncP-9 plasmids in a soil bacterial community. Appl. Environ. Microbiol. 2013, 80, 138-145. [CrossRef] [PubMed]

86. Klümper, U.; Riber, L.; Dechesne, A.; Sannazzarro, A.; Hansen, L.; Sørensen, S.; Smets, B. Broad host range plasmids can invade an unexpectedly diverse fraction of a soil bacterial community. ISME J. 2015, 9, 934-945. [CrossRef]

87. Smets, B.F.; Morrow, J.B.; Arango Pinedo, C. Plasmid introduction in metal-stressed, subsurface-derived microcosms: Plasmid fate and community response. Appl. Environ. Microbiol. 2003, 69, 4087-4097. [CrossRef]

88. Garbisu, C.; Garaiyurrebaso, O.; Epelde, L.; Grohmann, E.; Alkorta, I. Plasmid-mediated bioaugmentation for the bioremediation of contaminated soils. Front. Microbiol. 2017, 8, 1966. [CrossRef]

89. Matsui, K.; Endo, G. Mercury bioremediation by mercury resistance transposon-mediated in situ molecular breeding. Appl. Microbiol. Biotechnol. 2018, 102, 3037-3048. [CrossRef]

90. Liu, Y.; Zheng, Y.; Shen, J.; Zhang, L.; He, J. Effects of mercury on the activity and community composition of soil ammonia oxidizers. Environ. Sci. Pollut. R. 2010, 17, 1237-1244. [CrossRef]

91. van Dorst, J.; Siciliano, S.D.; Winsley, T.; Snape, I.; Ferrari, B.C. Bacterial targets as potential indicators of diesel fuel toxicity in subantarctic soils. Appl. Environ. Microbiol. 2014, 80, 4021-4033. [CrossRef]

92. Levy-Booth, D.J.; Prescott, C.E.; Grayston, S.J. Microbial functional genes involved in nitrogen fixation, nitrification and denitrification in forest ecosystems. Soil Biol. Biochem. 2014, 75, 11-25. [CrossRef]

93. Ke, X.; Lu, W.; Conrad, R. High oxygen concentration increases the abundance and activity of bacterial rather than archaeal nitrifiers in rice field soil. Microb. Ecol. 2015, 70, 961-970. [CrossRef] [PubMed]

94. Jung, J.; Yeom, J.; Kim, J.; Han, J.; Soo, H.L.; Park, H.; Hyun, S.; Park, W. Change in gene abundance in the nitrogen biogeochemical cycle with temperature and nitrogen addition in Antarctic soils. Res. Microbiol. 2011, 162, 1018-1026. [CrossRef] [PubMed]

95. Franche, C.; Lindström, K.; Elmerich, C. Nitrogen-fixing bacteria associated with leguminous and non-leguminous plants. Plant. Soil 2008, 321, 35-59. [CrossRef]

96. Lladó, S.; Grácia, E.; Solanas, A.M.; Viñas, M. Fungal and bacterial microbial community assessment during bioremediation assays in an aged creosote-polluted soil. Soil Biol. Biochem. 2013, 67, 114-123. [CrossRef]

Publisher's Note: MDPI stays neutral with regard to jurisdictional claims in published maps and institutional affiliations.

(C) 2020 by the authors. Licensee MDPI, Basel, Switzerland. This article is an open access article distributed under the terms and conditions of the Creative Commons Attribution (CC BY) license (http://creativecommons.org/licenses/by/4.0/). 